\title{
Synthesis of the C1-C12 Fragment of Calyculin C
}

\author{
Olga V. Konstantinova $a^{a, b}(D)$ \\ Ari M.P. Koskinen*a (iD \\ ${ }^{a}$ Aalto University School of Chemical Engineering, Depart- \\ ment of Chemistry and Materials Science, Kemistintie 1 \\ P.O. Box 16100, 02150 Espoo, Finland \\ ari.koskinen@aalto.fi \\ ${ }^{\mathrm{b}}$ Latvian Institute of Organic Synthesis, Aizkraukles 21, LV- \\ 1006, Riga, Latvia \\ Dedicated to the memory of Professor István E. Markó.
}

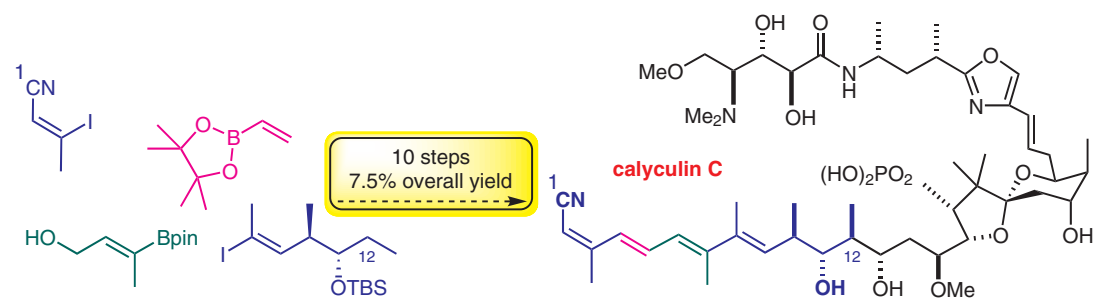

Published as part of the 50 Years SYNTHESIS - Golden Anniversary Issue

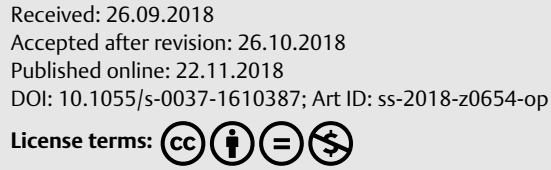

Abstract Calyculins are a class of highly cytotoxic metabolites originally isolated from the marine sponge Discodermia calyx. To date, a total of twelve different calyculins (A-J) and calyculinamides (A, B and F) have been described, the most abundant (in $D$. calyx) being calyculins $A$ and C. Herein, we demonstrate a concise route to access the $\mathrm{C} 1-\mathrm{C} 12$ tetraene fragment of calyculin C using transition-metal-catalyzed coupling reactions (Suzuki-Miyaura, Stille, Negishi and Heck) for the key connections. The synthesis starts from propionaldehyde and proceeds in 10 steps with $7.5 \%$ overall yield. We also describe an efficient route for the preparation of (Z)-3-iodobut-2-enenitrile in four steps and $68 \%$ yield.

Key words calyculins, natural products, transition-metal-catalyzed cross-coupling, Suzuki-Miyaura, Stille, Negishi and Heck coupling, syntheses of di- and polyenes

Calyculins are a class of highly cytotoxic metabolites originally isolated from the marine sponge Discodermia calyx by Fusetani et al. ${ }^{1}$ Later, other marine sponges containing calyculins and calyculinamides were found. ${ }^{2}$ To date, a total of twelve different calyculins (A-J) and calyculinamides ( $A, B$ and $F$ ) have been described, the most abundant (in D. calyx) being calyculins A and C (Scheme 1), which differ from each other only by methyl substitution at C32. The remaining calyculins are either geometric isomers of the calyculins A or C, or close derivatives of calyculin A: calyculinamides, ${ }^{3}$ dephosphonocalyculin $\mathrm{A},{ }^{4}$ geometricin and swinhoeiamide, ${ }^{5}$ and clavosines A-C. ${ }^{6}$ Structure-activity relationships and biosyntheses of these sponge-derived cytotoxins have been reviewed. ${ }^{7}$

These intriguing structures have inspired several research groups to devote significant synthetic efforts toward the calyculins, ${ }^{8}$ and these are summarized in Table 1.

We have been involved in the development of a synthetic access to calyculins and their analogues, and our chosen retrosynthesis is shown in Scheme 1. We have so far completed the syntheses of fragments $\mathrm{A}-\mathrm{C},{ }^{15}$ and have reported a synthesis of a tetraene fragment $\mathrm{D},{ }^{16}$ but which unfortunately is not attractive for large-scale efforts. Previous syntheses of the tetraene fragment $\mathrm{D}$ have been reported by Barrett, ${ }^{17}$ Shioiri ${ }^{18}$ and Armstrong. ${ }^{19}$

Transition-metal-catalyzed alkenyl-alkenyl cross-coupling reactions have proven to be effective in stereoselective syntheses of di- and polyenes and have been successfully applied to the total syntheses of a wide variety of natural products. ${ }^{20-23}$

Herein, we describe our recent results on the application of Pd-catalyzed cross-coupling reactions to the synthesis of the $\mathrm{C} 1-\mathrm{C} 12$ tetraene fragment $\mathbf{D}$ of calyculin $\mathrm{C}$. We tested the effectiveness of Stille, ${ }^{24}$ Negishi, ${ }^{25}$ Heck $^{26}$ and

Table 1 Overview of the Reported Total Syntheses of Calyculins

\begin{tabular}{|c|c|c|c|c|c|}
\hline Group & Target & No. of steps & Overall yield & Remarks & Ref. \\
\hline Evans & ent-calyculin A & 33 & $0.54 \%$ & total synthesis & 9 \\
\hline Masamune & calyculin A & 43 & $0.31 \%$ & total synthesis & 10 \\
\hline Shioiri & calyculin A & 32 & $0.092 \%$ & formal synthesis & 11 \\
\hline Smith & ent-calyculin A & 35 & $0.89 \%$ & formal synthesis & 12 \\
\hline Armstrong & calyculin C & 30 & $0.018 \%$ & total synthesis & 13 \\
\hline Barrett & ent-calyculin A & 34 & $0.9 \%$ & formal synthesis & 14 \\
\hline
\end{tabular}




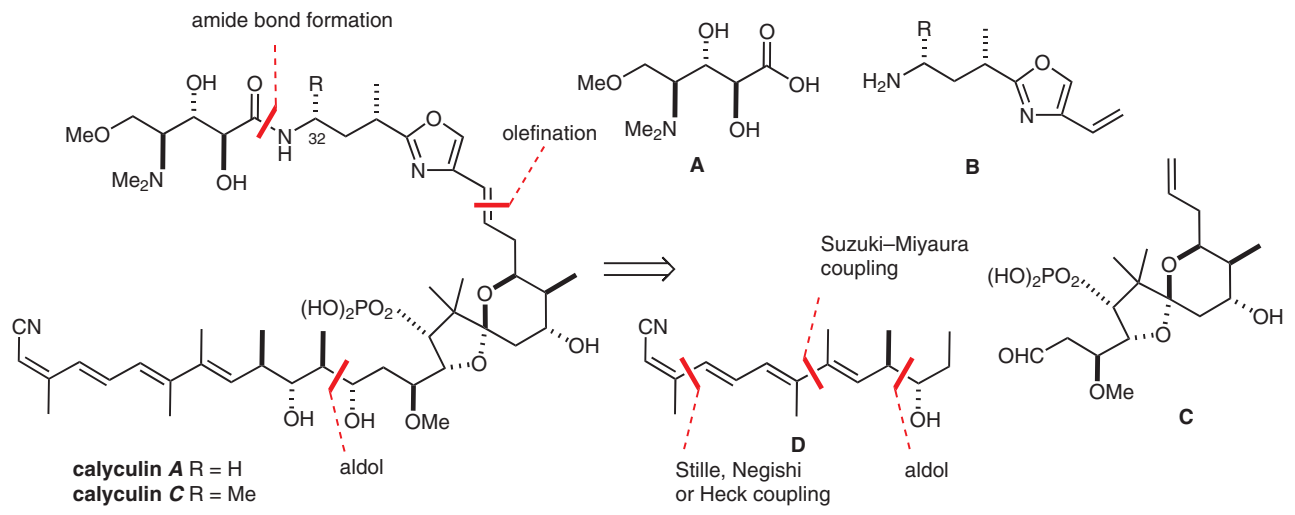

Scheme 1 Structures and retrosynthesis of calyculins A and C

Suzuki-Miyaura ${ }^{27}$ coupling strategies for the key connections of three precursors: iodonitrile $\mathbf{1}$, an appropriate component $\mathbf{2 , 3}$ or $\mathbf{4}$ and alcohol $\mathbf{5}$ (Scheme 2).

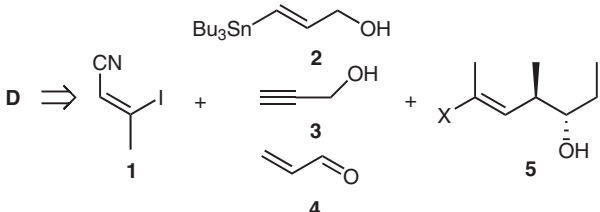

Scheme 2 Retrosynthetic analysis of the tetraene fragment $\mathbf{D}$ of calyculin C

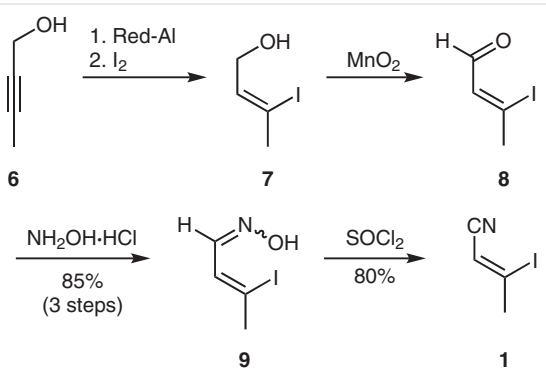

Scheme 3 Synthesis of iodonitrile 1 in four steps and 68\% overall yield from 2-butyn-1-ol (6)

The synthesis of iodonitrile $\mathbf{1}$ started with a one-pot Red-Al reduction of readily available 2-butyn-1-ol (6) followed by iodination to give alcohol $7 .{ }^{28}$ Oxidation of the pri- mary alcohol 7 with $\mathrm{MnO}_{2}$ gave aldehyde 8, which was converted into oxime 9 (as a mixture of isomers) in $85 \%$ yield over the three steps. Initial attempts to convert $\mathbf{9}$ into iodonitrile 1 using $\left(\mathrm{CF}_{3} \mathrm{CO}\right)_{2} \mathrm{O}$ and imidazole or $\mathrm{N}$-chlorosuccinimide and triphenylphosphine in $\mathrm{CH}_{2} \mathrm{Cl}_{2}$ proved unsuccessful. However, the desired conversion was achieved by treatment of 9 with thionyl chloride at $0{ }^{\circ} \mathrm{C}$, providing (Z)-3iodobut-2-enenitrile (1) as the only isomer in $68 \%$ overall yield in four steps (Scheme 3 ). The oximes $\mathbf{9}$ and iodonitrile 1 were found to be light- and temperature-sensitive but could be stored in a freezer in darkness for a long time (a year or more).

A Stille coupling was initially attempted in order to obtain adduct 11 (Scheme 4). Stannyl derivative $\mathbf{2}$ was prepared from propargylic alcohol (3) by several methods: a direct stannylcupration reaction ${ }^{29}$ with in situ generated $\mathrm{Bu}_{3} \mathrm{Sn}(\mathrm{Bu}) \mathrm{CuCNLi}_{2}$, a radical hydrostannylation reaction ${ }^{30}$ with $\mathrm{Bu}_{3} \mathrm{SnH}$ and $\mathrm{AIBN}$ at $80{ }^{\circ} \mathrm{C}$, or a $\mathrm{Pd}(0)$-catalyzed hydrostannylation reaction. ${ }^{31}$ Due to the formation of isomer mixtures, the yield of $\mathbf{2}$ obtained by these different methods varied from low to moderate, the best being obtained through direct stannylcupration. The large excess of toxic $\mathrm{Bu}_{3} \mathrm{SnH}$ required for full conversion of substrate 3 , the low yield and the necessity to separate isomers made this approach unattractive. Therefore, the Stille coupling of iodonitrile 1 with 2, although giving 11 stereoselectively in 39\% yield, was not optimized further.

The next attempt to prepare adduct $\mathbf{1 1}$ was through a Negishi coupling procedure. ${ }^{32}$ This alternative shorter route

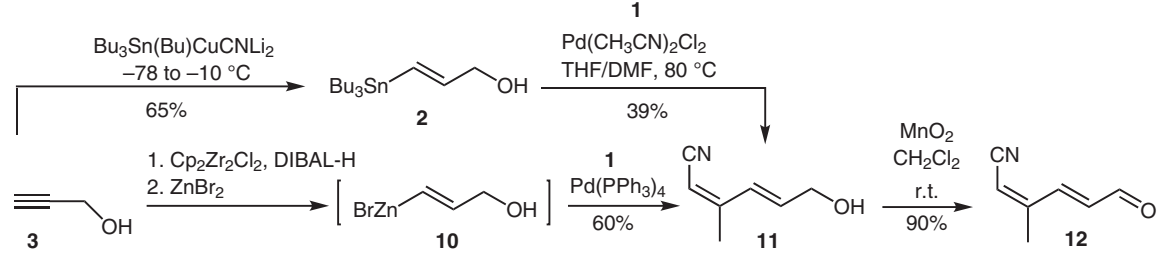

Scheme 4 Synthesis of conjugated aldehyde 12 by Stille and Negishi cross-coupling reactions 
included a one-pot Schwartz hydrozirconation of 3, transmetalation from $\mathrm{Zr}$ to $\mathrm{Zn}$ and a Pd-catalyzed cross-coupling of the vinylzinc intermediate $\mathbf{1 0}$ with iodonitrile $\mathbf{1}$ to provide 11 in 60\% yield as a single isomer. Oxidation of 11 with $\mathrm{MnO}_{2}$ afforded the conjugated aldehyde $\mathbf{1 2}$ in an excellent $90 \%$ yield (Scheme 4 ).

The Mizoroki-Heck cross-coupling reaction ${ }^{33 a, b}$ is a much more attractive method providing conjugated aldehyde 12 directly from 1 in one step (Scheme 5). Unfortunately, initial experiments showed that the reaction of iodonitrile 1 with acrolein (4) at room temperature yielded an inseparable mixture of two isomeric compounds 12 and 13 (Table 2, entries 1-3). The isomeric compound was likely to be diene 13 because of the typical trans double bond coupling constant $(J=15.8 \mathrm{~Hz})$ in the ${ }^{1} \mathrm{H}$ NMR spectrum and the low possibility of the formation of branched Heck coupling products with olefins containing an electron-withdrawing

Table 2 Conditions Screened for the Mizoroki-Heck Cross-Coupling of Iodonitrile 1 with Acrolein (4) Affording Conjugated Aldehyde 12

\begin{tabular}{|c|c|c|c|c|c|c|}
\hline Entry & Cat. & Base & $12: 13$ & $\begin{array}{l}\text { Conver- } \\
\text { sion }(\%)^{\mathrm{a}}\end{array}$ & $\begin{array}{l}\text { Yield } \\
(\%)^{\mathrm{b}}\end{array}$ & $\begin{array}{l}\text { Time } \\
\text { (d) }\end{array}$ \\
\hline $1^{c}$ & $\mathrm{PdCl}_{2}$ & $\mathrm{~K}_{2} \mathrm{CO}_{3}$ & $53: 47$ & full & 36 & 1 \\
\hline 2 & & $\mathrm{Ag}_{2} \mathrm{CO}_{3}$ & $73: 27$ & 15 & $\mathrm{NE}$ & 1 \\
\hline 3 & & KOAC & $75: 25$ & 80 & $\mathrm{NE}$ & 1 \\
\hline $4^{d}$ & & $\mathrm{AgOAc}$ & $95: 5$ & 12 & $\mathrm{NE}$ & 1 \\
\hline 5 & & & $95: 5$ & 80 & 40 & 1 \\
\hline 6 & $\mathrm{Pd}_{2}(\mathrm{dba})_{3}$ & AgOAc & $94: 6$ & 18 & NE & 1 \\
\hline 7 & $\mathrm{Pd}(\mathrm{acac})_{2}$ & & - & NR & - & 2 \\
\hline $8^{e}$ & $\mathrm{Pd}(\mathrm{OAc})_{2}$ & & $95: 5$ & 95 & 65 & 2 \\
\hline 9 & & & $95: 5$ & 95 & 85 & 2 \\
\hline 10 & & $\mathrm{CsOAC}$ & $82: 18$ & 99 & NE & 1 \\
\hline
\end{tabular}

${ }^{\text {a }}$ Conversions determined from the ${ }^{1} \mathrm{H}$ NMR spectra. $\mathrm{NR}=$ no reaction.

b Yield of isolated product 12. $\mathrm{NE}=$ not estimated.

${ }^{C} \mathrm{Bu}_{4} \mathrm{NF}$ (1 equiv) was added to the reaction mixture.

Instead of acetonitrile the same amount of acrolein was added.

$10 \mathrm{~mol} \% \mathrm{Pd}(\mathrm{OAc})_{2}$ was used.

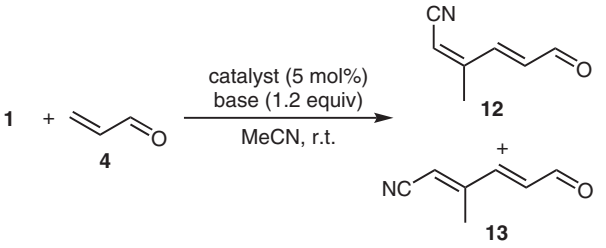

Scheme 5 Mizoroki-Heck cross-coupling of iodonitrile 1 with acrolein (4) affording conjugated aldehyde 12

carbonyl group, as found in acrolein. The only remaining possibility is the isomerization of the cyano group, which has been described previously. ${ }^{33 c}$

Some reactions (Table 2, entries 1 and 5) gave high conversions (determined from the ${ }^{1} \mathrm{H}$ NMR spectral data), but low isolated yields. A possible explanation is base-initiated iodine elimination in $\mathbf{1}$ and removal of volatile but-2-ynenitrile from the reaction mixture. Reaction times that were too long led to contamination of the product with polymerization or Diels-Alder cyclization by-products. After screening different catalysts and bases, we were fortunate to find conditions delivering the desired isomer 12 with 95\% isomeric purity and $85 \%$ yield (entry 9). The NMR data of this product were identical with those previously obtained for compound 12 prepared via different methods (Scheme 4).

Aldehyde 12 was next subjected to the Ramirez reaction $^{34}$ by treatment with the ylide formed in situ from triphenylphosphine and tetrabromomethane to give dibromide 14 (Scheme 6).

A Negishi-type reaction of dibromide 14 would require iodide 15, which was synthesized according to Scheme 7. Thus, alcohol $\mathbf{6}$ was reacted with Schwarz's reagent and then iodinated leading to iodide 21. Silylation then gave the protected iodide 15. However, attempts to couple 14 with the $\mathrm{Zn}$ reagent derived from iodide $\mathbf{1 5}$ in the presence of $\mathrm{Pd}\left(\mathrm{PPh}_{3}\right)_{4}$ failed.

Alternatively, the Suzuki-Miyaura coupling of dibromide 14 and olefin 16 gave the corresponding tetraene 17 (Scheme 6). ${ }^{35}$ The synthesis of $\mathbf{1 6}$ is shown later in Scheme 11. Treatment of $\mathbf{1 7}$ with $t$-BuMe ${ }_{2}$ SiOTf and 2,6-lutidine in

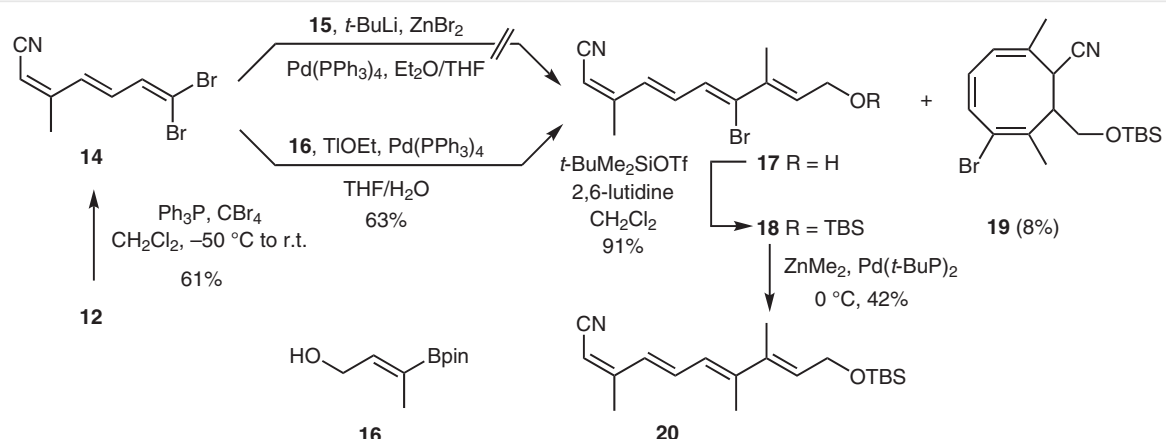

Scheme 6 Synthesis of tetraene $\mathbf{2 0}$ synthesis according to the first strategic plan 
dichloromethane at $-85^{\circ} \mathrm{C}$ led to the protected compound 18 in $91 \%$ yield along with a small amount of cyclized compound 19. Unfortunately, compound 18 showed a tendency to undergo spontaneous cyclization to give compound $\mathbf{1 9}$ during column chromatography or on standing in solution at room temperature. This type of Pd-catalyzed cyclization of conjugated tetraenes has been reported by Parker, ${ }^{36}$ Trauner $^{37}$ and Baldwin. ${ }^{38}$ Finally, the bromotetraene 18 was subjected to a Negishi cross-coupling using $\mathrm{ZnMe}_{2}$ and $\left[\mathrm{Pd}\left(t-\mathrm{Bu}_{3} \mathrm{P}\right)_{2}\right]^{39}$ to give tetraene $\mathbf{2 0}$.

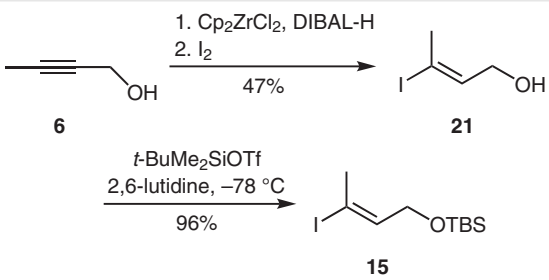

Scheme 7 Synthesis of iodide 15

As the approach to tetraene $\mathbf{2 0}$ was significantly complicated by the undesired formation of the cyclic compound 19, modifications according to Scheme 8 were undertaken to avoid the undesired cyclization.

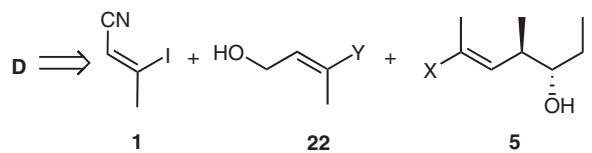

Scheme 8 Modified retrosynthetic analysis of tetraene fragment D

The synthesis of the key compound $\mathbf{5}$ started with selfaldol condensation of propionaldehyde (23) catalyzed by 4trans-hydroxy-L-proline in $\mathrm{DMSO}^{40}$ to give $\mathbf{2 4}$ as a 6:1 anti/syn diastereomeric mixture (determined by ${ }^{1} \mathrm{H}$ NMR) (Scheme 9). Unfortunately, the next step, silylation with tert-butyldimethylsilyl triflate and diisopropylethylamine in dichloromethane at $0{ }^{\circ} \mathrm{C}$, was accompanied by partial racemization at the labile $\alpha$-stereogenic center leading to compound $\mathbf{2 5}$ in $76 \%$ yield ( 2 steps from 23 ), but a diastereomeric ratio of 2:1 (anti/syn). The protected compound 25 was subjected to the Ramirez reaction and the dibromoolefins $\mathbf{2 6}$ and $\mathbf{2 7}$ were separated through column chromatography on silica gel to afford the desired diastereomer $\mathbf{2 6}$ as the major product. Dibromide $\mathbf{2 6}$ was then subjected to a Corey-Fuchs alkynylation step. ${ }^{41}$ Thus, elimination with $n$-butyllithium and methylation with iodomethane gave intermediate $\mathbf{2 8}$ in excellent yield. Sequential hydrozirconation of $\mathbf{2 8}$ with Schwartz's reagent ${ }^{42}$ (obtained in situ from $\mathrm{Cp}_{2} \mathrm{ZrCl}_{2}$ and DIBAL-H) and iodination afforded iodide 29 in $65 \%$ yield.

The enantiomeric composition of the obtained chiral compounds was determined according to the Mosher method. ${ }^{43}$ Deprotection of $\mathbf{2 6}$ with $n$ - $\mathrm{Bu}_{4} \mathrm{NF}$ at $45-50{ }^{\circ} \mathrm{C}$ proceeded with dehydrobromination leading to monobromo-substituted 30. Improved results were obtained when $\mathbf{2 8}$ was deprotected under the same conditions to give the more stable compound 31 (Scheme 10), which was then subjected to derivatization with Mosher's acid chlorides. ${ }^{44}$ NMR analysis established a 70\% enantiomeric excess for alkyne $\mathbf{2 8}$ (see the Supporting Information).

Only a few approaches to the anti diastereomer of $\mathbf{2 4}$ or its precursors with high de and ee values, requiring multistep syntheses, are described..$^{45}$ When we first tested the key steps of the approach (see Scheme 8), we gave preference to the shorter synthetic route to compound $\mathbf{2 9}$ with lower ee over the longer synthetic route with higher ee.
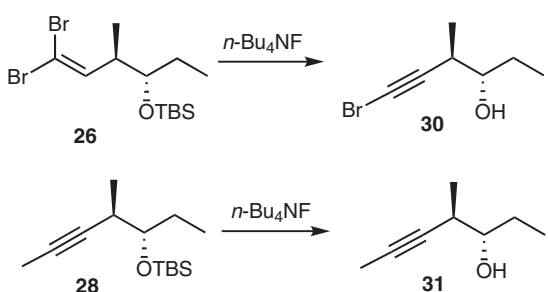

Scheme 10 Synthesis of compounds for derivatization with Mosher's acid chlorides to establish the enantiomeric excesses of their precursors
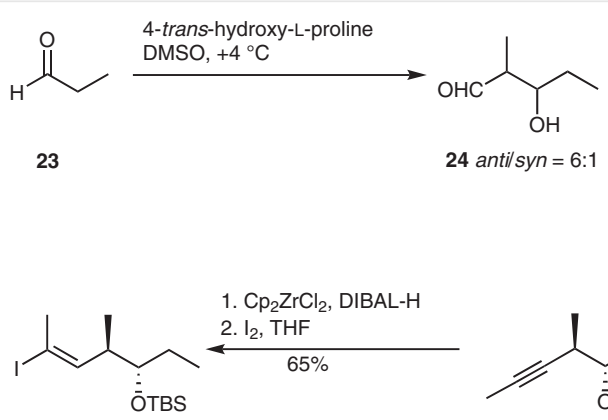

29

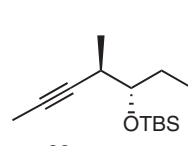

28

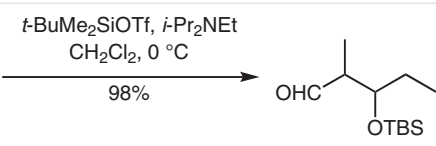

25 anti/syn $=2: 1$

1. $\mathrm{Ph}_{3} \mathrm{P}, \mathrm{CBr}_{4}$

2. column chromatography

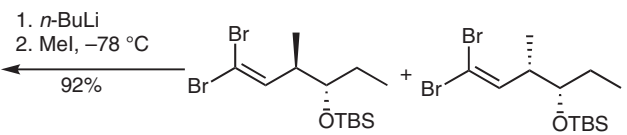

26
27

Scheme 9 Synthetic route to $\mathbf{2 9}$ representing key compound $\mathbf{5}$ 


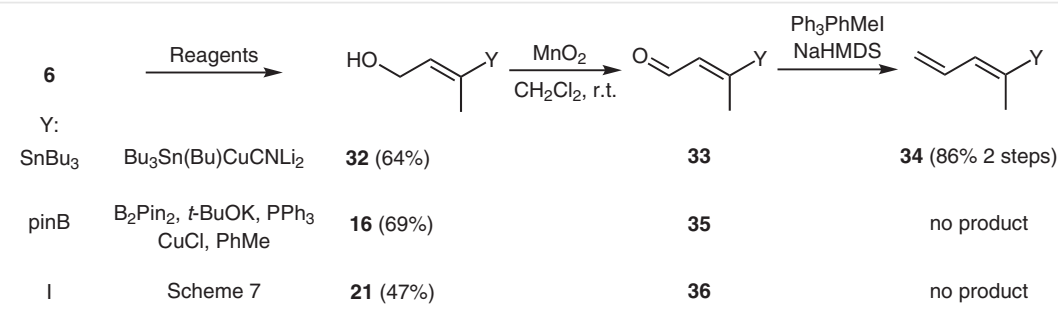

Scheme 11 Syntheses of the components for transition-metal-catalyzed cross-coupling reactions with iodide 29

In multistep syntheses a convergent strategy is much more advantageous over a linear one. We therefore prepared three compounds, $32,{ }^{29} \mathbf{1 6}^{46}$ and $\mathbf{2 1}$, and planned to modify them according to Scheme 11. A further intention was the Heck coupling of the obtained diene with $\mathbf{1}$ and final assembly of the resulting triene with key compound $\mathbf{5}$ (i.e., vinyl iodide $\mathbf{2 9}$ ) in the last step.

Only the tin derivative $\mathbf{3 4}$ was obtained with a satisfactory yield according to this scheme. All attempts to convert 34 into compound 37 by metathesis with 4,4,5,5-tetramethyl-2-vinyl-1,3,2-dioxaborolane led to complex reaction mixtures with low yields of $\mathbf{3 7}$ (Scheme 12). The reaction of $\mathbf{3 4}$ with 1 resulted in formation of the Stille coupling product instead of the desired Heck coupling product.

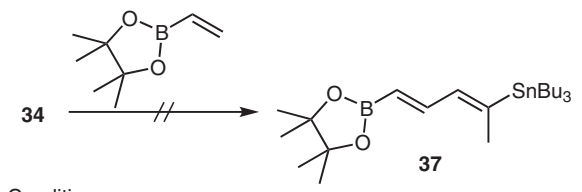

Conditions:

Hoveyda-Grubbs $1^{\text {st }}$ generation, $\mathrm{CH}_{2} \mathrm{Cl}_{2}, 40^{\circ} \mathrm{C}$

or Hoveyda-Grubbs $2^{\text {nd }}$ generation, $\mathrm{CH}_{2} \mathrm{Cl}_{2}, 35^{\circ} \mathrm{C}$

or Hoveyda-Grubbs $1^{\text {st }}$ generation, $\mathrm{CH}_{2} \mathrm{Cl}_{2}$, r.t.

or Grubbs $1^{\text {st }}$ generation, $\mathrm{CH}_{2} \mathrm{Cl}_{2}$, r.t.

Scheme 12 Screened conditions for metathesis reactions of $\mathbf{3 4}$ with 4,4,5,5-tetramethyl-2-vinyl-1,3,2-dioxaborolane

The $\mathrm{Pd}\left(\mathrm{PPh}_{3}\right)_{4}$-catalyzed Suzuki-Miyaura coupling of vinylboronate $\mathbf{1 6}$ with iodide $\mathbf{2 9}$ proceeded stereoselectively with $95 \%$ yield to give the conjugated diene $\mathbf{3 8}$ with two trisubstituted double bonds (Scheme 13). Oxidation with $\mathrm{MnO}_{2}$ afforded aldehyde 39, which was subjected to Wittig olefination to yield the conjugated triene $\mathbf{4 0}$.

Inspired by the successful Mizoroki-Heck coupling of $\mathbf{1}$ with acrolein (4) (see Scheme 5), we first tried to apply the same conditions to couple triene $\mathbf{4 0}$ with iodonitrile $\mathbf{1}$ (Scheme 14). As AgOAc had demonstrated the best stereoselectivity in this reaction, we opted for AgOAc as the base again and no other bases were tested. However, the best conditions from Table 2 were not a guarantee of the desired result for the reaction of iodonitrile 1 with triene $\mathbf{4 0}$. All experiments yielded a mixture of isomers, which were not separated into individual components. One of the compo-

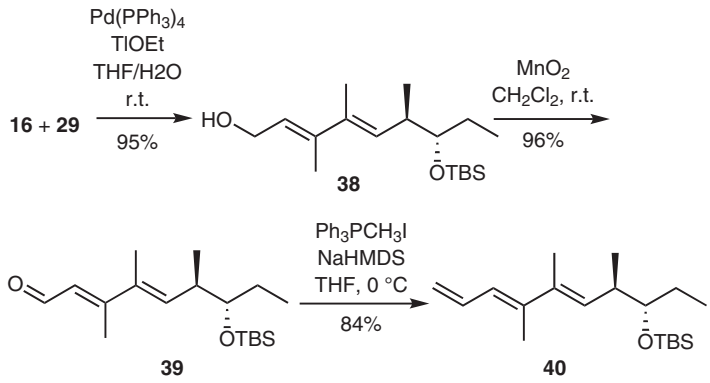

Scheme 13 Synthetic route to triene $\mathbf{4 0}$

nents was tetraene 41, the ${ }^{1} \mathrm{H}$ NMR data of which were identical to those of the same compound obtained later through Suzuki-Miyaura coupling according to Scheme 15. Analysis of the spectral data of the second component most likely showed the formation of isomer $\mathbf{4 2}$ instead of $\mathbf{4 3}$.

Despite the lack of high stereoselectivity this reaction is interesting because, to the best of our knowledge, it is one of only a few examples of the Heck coupling of vinyl halides with nonaromatic trienes. ${ }^{47}$

Metathesis of $\mathbf{4 0}$ with 4,4,5,5-tetramethyl-2-vinyl-1,3,2dioxaborolane in dichloromethane at room temperature gave triene $\mathbf{4 5}$ (Scheme 15), which was reacted with iodo-

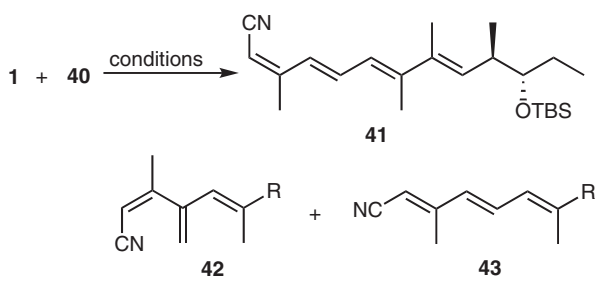

define $\mathrm{R}$ here, $\mathrm{R}=\mathrm{C}\left(\mathrm{CH}_{3}\right)=\mathrm{CHCH}\left(\mathrm{CH}_{3}\right) \mathrm{CH}(\mathrm{OTBS}) \mathrm{CH}_{2} \mathrm{CH}_{3}$

$\begin{array}{llc}\text { Conditions: catalyst }(10 \mathrm{~mol} \%) \\ \text { AgOAc (3 equiv), } \mathrm{MeCN}, 21-24 \mathrm{~h} \\ \text { Catalyst } & \mathbf{T},\left({ }^{\circ} \mathrm{C}\right) & \mathbf{4 1 : 4 2} \\ \mathrm{Pd}(\mathrm{OAc})_{2} & \text { r.t. } & - \\ \mathrm{Pd}(\mathrm{OAc})_{2} & 30 & 72: 28 \\ \mathrm{Pd}(\mathrm{OAc})_{2} & 85-90 & \text { complex mixture } \\ \mathrm{PdCl}_{2} & 37 & 58: 42\end{array}$

Scheme 14 Mizoroki-Heck cross-coupling reaction of triene $\mathbf{4 0}$ with iodide 1 


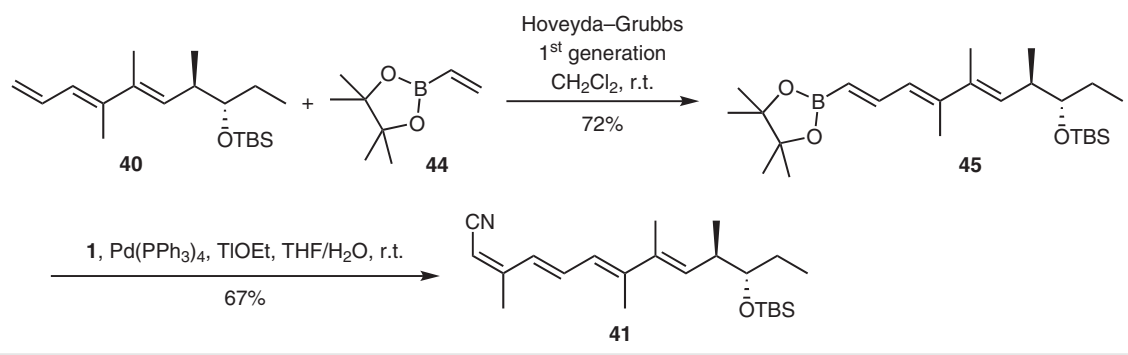

Scheme 15 Final steps in the synthesis of tetraene $\mathbf{4 1}$ according to the second strategic plan

nitrile $\mathbf{1}$ via a Suzuki-Miyaura coupling to afford the desired tetraene 41. The chemical shifts and coupling constants in the ${ }^{1} \mathrm{H}$ NMR of the obtained tetraene $\mathbf{4 1}$ matched very well with the same parameters described previously for an analogous tetraene fragment. ${ }^{48}$

In summary, we have demonstrated a concise route to access the $\mathrm{C} 1-\mathrm{C} 12$ tetraene fragment $\mathbf{4 1}$ of calyculin $\mathrm{C}$. The synthesis starts from propionaldehyde (23) and proceeds in 10 steps with $7.5 \%$ overall yield. We have also described an efficient route for the preparation of $(Z)$-3-iodobut-2-enenitrile (1) in four steps and $68 \%$ overall yield.

Moisture-sensitive reactions were carried out under an argon atmosphere, and glassware was flame-dried under high vacuum or in an oven. Dry solvents (THF, $\mathrm{Et}_{2} \mathrm{O}$, toluene, $\mathrm{MeCN}, \mathrm{CH}_{2} \mathrm{Cl}_{2}$ ) were obtained using an MBraun MB-SPS 800 solvent drying system. Commercial reagents were used without further purification. $\mathrm{Ph}_{3} \mathrm{P}$ was recrystallized from hot ethanol and was dried over $\mathrm{P}_{2} \mathrm{O}_{5}$ under vacuum. $n$-BuLi was titrated with $\mathrm{N}$-benzylbenzamide. Other solvents and reagents were used as received. Analytical TLC was performed using Merck silica gel (60, F254 230-400 mesh) precoated aluminum plates and samples were made visual by UV light $(\lambda=250 \mathrm{~nm})$ and/or staining upon heating with standard $\mathrm{KMnO}_{4}$, anisaldehyde or PMA solutions. Flash chromatography was carried out using Merck silica gel (60, F254 230-400 mesh) and p.a. grade solvents. IR spectra were recorded with Perkin-Elmer ONE FTIR or Bruker ALPHA ECO ATR FTIR spectrometers. ${ }^{1} \mathrm{H}$ and ${ }^{13} \mathrm{C}$ NMR spectra were recorded with a Bruker Avance DPX-400 spectrometer $\left({ }^{1} \mathrm{H}: 400 \mathrm{MHz} ;{ }^{13} \mathrm{C}: 101 \mathrm{MHz}\right)$. The chemical shifts are reported in ppm relative to TMS as the internal standard $(\delta=0.00)$ or the residual solvent signal $\left({ }^{1} \mathrm{H} \mathrm{NMR}: \mathrm{CDCl}_{3}, \delta=\right.$ $7.26 ;{ }^{13} \mathrm{C} \mathrm{NMR:} \mathrm{CDCl}_{3}, \delta=77.16$ ). Multiplicities are indicated by $\mathrm{s}$ ( singlet), d (doublet), t (triplet), q (quartet), m (multiplet) and br (broad). HRMS were obtained using a Waters Micromass LCT Premier (ESI) spectrometer.

\section{(Z)-3-Iodobut-2-enenitrile (1)}

To a solution of oxime $\mathbf{9}(0.5 \mathrm{~g}, 2.4 \mathrm{mmol})$ in THF ( $8 \mathrm{~mL})$ cooled to $5{ }^{\circ} \mathrm{C}$ under an inert atmosphere was added dropwise $\mathrm{SOCl}_{2}(0.26 \mathrm{~mL}$, $3.6 \mathrm{mmol}$ ) and the resulting mixture was stirred for $30 \mathrm{~min}$. It was then poured into a saturated aqueous solution of ice-cold $\mathrm{NaHCO}_{3}$ and extracted with $\mathrm{CH}_{2} \mathrm{Cl}_{2}$. The combined organic extracts were dried over $\mathrm{Na}_{2} \mathrm{SO}_{4}$, filtered and concentrated under reduced pressure (140 mbar) without heating. The residue was purified by column chromatography on silica gel ( $\mathrm{PE} / \mathrm{Et}_{2} \mathrm{O}, 40: 1$ to $\left.15: 1\right)$ to give compound 1 $(0.36 \mathrm{~g}, 80 \%)$ as a colorless oil.
IR (thin film): 3397, 2975, 2937, 2226, 1614, 1461, 1364, 1272, 1178, $1101,838,793 \mathrm{~cm}^{-1}$.

${ }^{1} \mathrm{H} \mathrm{NMR}\left(400 \mathrm{MHz}, \mathrm{CDCl}_{3}\right): \delta=6.13(\mathrm{q}, J=1.6 \mathrm{~Hz}, 1 \mathrm{H}), 2.68(\mathrm{~d}, J=1.6$ $\mathrm{Hz}, 3 \mathrm{H})$.

${ }^{13} \mathrm{C}$ NMR (101 MHz, $\left.\mathrm{CDCl}_{3}\right): \delta=122.84,118.21,110.28,34.72$.

HRMS (ESI): $\mathrm{m} / z$ [M $+\mathrm{Na}]^{+}$calcd for $\mathrm{C}_{4} \mathrm{H}_{4} \mathrm{NNaI}$ : 215.9286; found: 215.9283.

\section{(E)-3-(Tributylstannyl)prop-2-en-1-ol (2)}

Stannylcupration of propargylic alcohol (3) with in situ generated $\mathrm{Bu}_{3} \mathrm{Sn}(\mathrm{Bu}) \mathrm{CuCNLi}_{2}$ was performed according to the reported procedure.[29]

\section{(Z)-3-Iodobut-2-en-1-ol (7)}

A solution of Red-Al ${ }^{\circledR}(65 \%$ in toluene, $9 \mathrm{~mL}$, $\approx 3.5 \mathrm{M}, 31.5 \mathrm{mmol}$ ) was added dropwise over $1 \mathrm{~h}$ to a solution of 2-butyn-1-ol (6) (1.59 g, 22.7 $\mathrm{mmol})$ in dry $\mathrm{Et}_{2} \mathrm{O}(35 \mathrm{~mL})$ at $0{ }^{\circ} \mathrm{C}$ under an inert atmosphere. The reaction mixture was allowed to warm slowly to r.t. and was stirred at ambient temperature overnight. After the starting material had been completely consumed (TLC monitoring), the mixture was cooled to $0{ }^{\circ} \mathrm{C}$ and EtOAC $(1.8 \mathrm{~mL})$ was added dropwise. The mixture was then cooled to $-78{ }^{\circ} \mathrm{C}$ and a solution of $\mathrm{I}_{2}(8.65 \mathrm{~g}, 34.1 \mathrm{mmol})$ in THF (25 $\mathrm{mL}$ ) was added dropwise over $1.5 \mathrm{~h}$. After $30 \mathrm{~min}$, the cooling bath was removed and stirring was continued at r.t. for $1 \mathrm{~h}$. The mixture was then poured into an ice-cold saturated aqueous solution of $\mathrm{Na}_{2} \mathrm{~S}_{2} \mathrm{O}_{3}$ and extracted with $\mathrm{Et}_{2} \mathrm{O}$. The combined organic fractions were dried over $\mathrm{Na}_{2} \mathrm{SO}_{4}$, filtered and concentrated under reduced pressure (50 mbar) without heating to give $4.5 \mathrm{~g}$ (quant.) of crude compound 7 as a colorless oil, which was used in the next step without purification. Pure compound 7 was obtained by column chromatography on silica gel (hexane/EtOAc, 5:1). The spectroscopic data are consistent with reported literature data.[49,50]

\section{(2Z)-3-Iodobut-2-enal Oxime (9)}

To a solution of alcohol 7 (4.5 g) in $\mathrm{CH}_{2} \mathrm{Cl}_{2}(100 \mathrm{~mL})$ was added $\mathrm{MnO}_{2}$ $(22 \mathrm{~g}, 253 \mathrm{mmol})$ portionwise. When the reaction was complete, the $\mathrm{MnO}_{2}$ was removed by filtration through a pad of Celite ${ }^{\circledR}$ and the pad was rinsed with $\mathrm{CH}_{2} \mathrm{Cl}_{2}$. The filtrate was concentrated under reduced pressure (250 mbar) without heating. The residue was dissolved in THF $(30 \mathrm{~mL})$ and $\mathrm{NH}_{2} \mathrm{OH} \cdot \mathrm{HCl}(1.9 \mathrm{~g}, 27.3 \mathrm{mmol}), \mathrm{H}_{2} \mathrm{O}(7 \mathrm{~mL})$ and $\mathrm{NaHCO}_{3}(1.9 \mathrm{~g}, 22.7 \mathrm{mmol})$ were added portionwise. The reaction mixture was stirred at r.t. for $20 \mathrm{~min}$ and then poured into a saturated aqueous solution of $\mathrm{NaHCO}_{3}$ and extracted with $\mathrm{CH}_{2} \mathrm{Cl}_{2}$. The combined organic fractions were dried over $\mathrm{Na}_{2} \mathrm{SO}_{4}$, filtered, and concentrated under vacuum without heating. The residue was purified by column chromatography on silica gel (hexane/ $\mathrm{Et}_{2} \mathrm{O}, 40: 1$ to $20: 1$ ) to 
give 9 as a slightly yellow solid [4.0 g, 84\% from 2-butyn-1-ol (6)]. This compound was very light-sensitive and should be stored in a freezer at $-18{ }^{\circ} \mathrm{C}$ in the dark.

IR (thin film): 3160, 3042, 2865, 2772, 1633, 1478, 1423, 1309, 1261, $1080,1015,974,934,839,726 \mathrm{~cm}^{-1}$.

${ }^{1} \mathrm{H} \mathrm{NMR}\left(400 \mathrm{MHz}, \mathrm{CDCl}_{3}\right): \delta=9.92(\mathrm{br} \mathrm{s}, 1 \mathrm{H}), 7.87(\mathrm{~d}, J=9.1 \mathrm{~Hz}, 0.62$ H), 7.20 (d, $J=8.5 \mathrm{~Hz}, 0.34 \mathrm{H}), 6.87$ (d, $J=8.5 \mathrm{~Hz}, 0.34 \mathrm{H}), 6.28$ (dd, $J=$ 9.1, $1.4 \mathrm{~Hz}, 0.64 \mathrm{H}), 2.71$ (d, J = 1.5 Hz, $1.05 \mathrm{H}), 2.66$ (s, $1.93 \mathrm{H})$.

${ }^{13} \mathrm{C}$ NMR $\left(101 \mathrm{MHz}, \mathrm{CDCl}_{3}\right): \delta=154.96,150.91,127.86,122.84$, 113.02, 109.22, 35.33, 34.95 .

HRMS (ESI): $m / z$ [M $+\mathrm{Na}]^{+}$calcd for $\mathrm{C}_{4} \mathrm{H}_{6} \mathrm{NONaI}$ : 233.9392; found: 233.9383.

(2Z,4E)-6-Hydroxy-3-methylhexa-2,4-dienenitrile (11) (1 ${ }^{\text {st }}$ Method) A mixture of iodide $\mathbf{1}$ ( $80 \mathrm{mg}, 0.4146 \mathrm{mmol}$ ), stannyl derivative $\mathbf{2}$ (140 $\mathrm{mg}, 0.4146 \mathrm{mmol})$ and $\mathrm{Pd}\left(\mathrm{CH}_{3} \mathrm{CN}\right)_{2} \mathrm{Cl}_{2}(11 \mathrm{mg}, 0.0414 \mathrm{mmol}, 0.1$ equiv) in THF $(1.5 \mathrm{~mL})$ and $\operatorname{DMF}(1.5 \mathrm{~mL})$ was heated at $80{ }^{\circ} \mathrm{C}$ under argon for $22 \mathrm{~h}$. The reaction mixture was poured into a saturated solution of brine and extracted with EtOAc. The combined organic fractions were dried over $\mathrm{Na}_{2} \mathrm{SO}_{4}$ and concentrated under vacuum. The residue was purified by column chromatography on silica gel (hexane/EtOAc, 10:1 to 1:3) to give adduct 11 as a colorless oil (20 mg, $39 \%)$.

(2Z,4E)-6-Hydroxy-3-methylhexa-2,4-dienenitrile (11) (2 $2^{\text {nd }}$ Method) The adduct $\mathbf{1 1}$ was also obtained by a slightly modified procedure.[32] Under argon at $0{ }^{\circ} \mathrm{C}$, DIBAL-H $(0.62 \mathrm{~mL}, 1 \mathrm{M}$ in hexane, 0.62 mmol, 1.5 equiv) was added slowly via syringe to a solution of alcohol 3 (35 mg, $0.62 \mathrm{mmol}, 1.5$ equiv) in THF $(0.3 \mathrm{~mL})$ and the resulting solution was allowed to warm to r.t. and stirred for $1 \mathrm{~h}$. In another flask covered with aluminum foil under argon were added $\mathrm{Cp}_{2} \mathrm{ZrCl}_{2}$ (363 mg, $1.24 \mathrm{mmol}, 3$ equiv) and THF ( $2 \mathrm{~mL}$ ). To this mixture was added dropwise DIBAL-H $(1.24 \mathrm{~mL}, 1 \mathrm{M}$ in hexane, $1.24 \mathrm{mmol}, 3$ equiv) at $0{ }^{\circ} \mathrm{C}$. After $30 \mathrm{~min}$, the pretreated alcohol mixture was transferred via cannula into the second reaction flask and the resulting mixture was stirred at r.t. for $2 \mathrm{~h}$ until all the solid had dissolved. Next, a solution of $\mathrm{ZnBr}_{2}$ ( $280 \mathrm{mg}, 1.24 \mathrm{mmol}, 3$ equiv) in THF $(1.5 \mathrm{~mL})$ was added via cannula. After $15 \mathrm{~min}$, a solution of $\mathbf{1}(80 \mathrm{mg}, 0.41$ mmol, 1 equiv) and $\mathrm{Pd}\left(\mathrm{PPh}_{3}\right)_{4}$ (48 mg, $0.04 \mathrm{mmol}, 0.1$ equiv) in THF $(0.9 \mathrm{~mL})$ was transferred via cannula and the reaction mixture was left stirring overnight. The mixture was diluted with $\mathrm{Et}_{2} \mathrm{O}$ and quenched with saturated $\mathrm{NH}_{4} \mathrm{Cl}$ solution. The mixture was then extracted with $\mathrm{Et}_{2} \mathrm{O}$ and the combined organic layers were dried over $\mathrm{Na}_{2} \mathrm{SO}_{4}$, filtered and concentrated under vacuum. The residue was purified by column chromatography on $\mathrm{SiO}_{2}\left(\mathrm{PE} / \mathrm{Et}_{2} \mathrm{O}, 30: 1\right.$ to $\left.1: 10\right)$ to give 11 as a colorless oil ( $37 \mathrm{mg}, 60 \%$ ).

IR (thin film): 3412, 2212, 1643, 1585, 1436, 1097, $965 \mathrm{~cm}^{-1}$.

${ }^{1} \mathrm{H}$ NMR $\left(400 \mathrm{MHz}, \mathrm{CDCl}_{3}\right): \delta=6.86(\mathrm{dt}, J=15.7,1.7 \mathrm{~Hz}, 1 \mathrm{H}), 6.27$ (dtd, $J=15.7,5.1,0.5 \mathrm{~Hz}, 1 \mathrm{H}), 5.20-5.14(\mathrm{~m}, 1 \mathrm{H}), 4.34$ (dd, $J=5.1,1.3$ $\mathrm{Hz}, 2 \mathrm{H}), 2.02(\mathrm{~d}, J=1.4 \mathrm{~Hz}, 3 \mathrm{H})$.

${ }^{13} \mathrm{C}$ NMR $\left(101 \mathrm{MHz}, \mathrm{CDCl}_{3}\right): \delta=156.06,137.92,127.44,116.80,96.53$, $62.84,19.61$.

HRMS (ESI): $m / z[\mathrm{M}+\mathrm{Na}]^{+}$calcd for $\mathrm{C}_{7} \mathrm{H}_{9} \mathrm{NONa}$ : 146.0582 ; found: 146.0582 .

\section{(2Z,4E)-3-Methyl-6-oxohexa-2,4-dienenitrile (12) ( $1^{\text {st }}$ Method)}

To a solution of alcohol 11 (18 mg, $0.15 \mathrm{mmol}, 1$ equiv) in $\mathrm{CH}_{2} \mathrm{Cl}_{2}(1$ $\mathrm{mL}$ ) was added $\mathrm{MnO}_{2}$ (190 mg, $2.19 \mathrm{mmol}, 15$ equiv) portionwise and the resulting mixture was stirred at r.t. When the reaction was com- plete, $\mathrm{MnO}_{2}$ was removed by filtration through a pad of Celite ${ }^{\circledR}$ and the pad was rinsed with $\mathrm{CH}_{2} \mathrm{Cl}_{2}$. The filtrate was concentrated under vacuum to give 12 as a colorless oil ( $16 \mathrm{mg}, 90 \%$ ).

\section{(2Z,4E)-3-Methyl-6-oxohexa-2,4-dienenitrile (12) ( ${ }^{\text {nd }}$ Method)}

To a solution of $\mathbf{1}(97 \mathrm{mg}, 0.50 \mathrm{mmol}, 1$ equiv) in $\mathrm{MeCN}(2 \mathrm{~mL})$ covered with aluminum foil were added acrolein (4) $(0.33 \mathrm{ml}, 5.03 \mathrm{mmol}, 10$ equiv), $\mathrm{Pd}(\mathrm{OAc})_{2}(6 \mathrm{mg}, 0.025 \mathrm{mmol}, 5 \mathrm{~mol} \%)$ and $\mathrm{AgOAc}(100 \mathrm{mg}$, $0.60 \mathrm{mmol}, 1.2$ equiv) and reaction mixture was stirred under argon in the dark for $48 \mathrm{~h}$ at r.t. The mixture was filtered through a pad of $\mathrm{SiO}_{2}$, the pad was rinsed with $\mathrm{Et}_{2} \mathrm{O}$ and the filtrate was concentrated under vacuum. The residue was purified by column chromatography on $\mathrm{SiO}_{2}$ (hexane/ $\mathrm{Et}_{2} \mathrm{O}, 15: 1$ to $\left.1: 1\right)$ to give $\mathbf{1 2}(52 \mathrm{mg}, 85 \%)$.

IR (thin film): 2217, 1682, 1132, 985, $862 \mathrm{~cm}^{-1}$.

${ }^{1} \mathrm{H}$ NMR $\left(400 \mathrm{MHz}, \mathrm{CDCl}_{3}\right): \delta=9.77(\mathrm{~d}, J=7.6 \mathrm{~Hz}, 1 \mathrm{H}), 7.63(\mathrm{dd}, J=$ $15.9,0.5 \mathrm{~Hz}, 1 \mathrm{H}$ ), 6.43 (ddd, $J=15.8,7.6,0.4 \mathrm{~Hz}, 1 \mathrm{H}$ ), 5.56-5.57 (m, 1 $\mathrm{H}), 2.13(\mathrm{~d}, J=1.5 \mathrm{~Hz}, 3 \mathrm{H})$.

${ }^{13} \mathrm{C}$ NMR $\left(101 \mathrm{MHz}, \mathrm{CDCl}_{3}\right): \delta=193.26,153.77,146.04,134.39$, 115.47, 104.55, 19.36.

HRMS (ESI): $m / z[\mathrm{M}+\mathrm{Na}]^{+}$calcd for $\mathrm{C}_{7} \mathrm{H}_{7} \mathrm{NONa}$ : 144.0425; found: 144.0422 .

\section{(2Z,4E)-7,7-Dibromo-3-methylhepta-2,4,6-trienenitrile (14)}

To a solution of $\mathrm{Ph}_{3} \mathrm{P}(2.2 \mathrm{~g}, 8.59 \mathrm{mmol}, 8$ equiv $)$ in dry $\mathrm{CH}_{2} \mathrm{Cl}_{2}(20 \mathrm{~mL})$ cooled to $0{ }^{\circ} \mathrm{C}$ under an inert atmosphere was added a solution of $\mathrm{CBr}_{4}$ (306 mg, $4.29 \mathrm{mmol}, 4$ equiv) in dry $\mathrm{CH}_{2} \mathrm{Cl}_{2}(5 \mathrm{~mL}$ ). After $10 \mathrm{~min}$, the mixture turned yellow and was cooled to $-50{ }^{\circ} \mathrm{C}$. A solution of aldehyde 12 (130 mg, $1.07 \mathrm{mmol}, 1$ equiv) in dry $\mathrm{CH}_{2} \mathrm{Cl}_{2}(1 \mathrm{~mL})$ was added dropwise at the same temperature. The mixture was then allowed to warm to r.t. over $2 \mathrm{~h}$ until the reaction was complete. Hexane was added and the obtained precipitate was removed by filtration. The filtrate was concentrated under vacuum and the residue was purified by column chromatography on silica gel (hexane) to give dibromide $\mathbf{1 4}$ (180 $\mathrm{mg}, 61 \%$ ) as a white solid.

IR (thin film): 2211, 1603, 1548, 1440, 1354, 1211, 962, $806 \mathrm{~cm}^{-1}$.

${ }^{1} \mathrm{H}$ NMR $\left(400 \mathrm{MHz}, \mathrm{CDCl}_{3}\right): \delta=7.13(\mathrm{dd}, J=10.4,0.6 \mathrm{~Hz}, 1 \mathrm{H}), 6.94(\mathrm{~d}$, $J=15.4 \mathrm{~Hz}, 1 \mathrm{H}$ ), 6.58 (ddd, $J=15.3,10.4,0.4 \mathrm{~Hz}, 1 \mathrm{H}), 5.29$ (d, $J=0.5$ $\mathrm{Hz}, 1 \mathrm{H}), 2.08(\mathrm{~d}, J=1.2 \mathrm{~Hz}, 3 \mathrm{H})$.

${ }^{13} \mathrm{C}$ NMR (101 MHz, $\left.\mathrm{CDCl}_{3}\right): \delta=155.43,136.30,132.47,131.87$, 116.69, 98.91, 97.29, 19.28.

HRMS (ESI): $m / z[\mathrm{M}+\mathrm{Na}]^{+}$calcd for $\mathrm{C}_{8} \mathrm{H}_{7} \mathrm{NNaBr}_{2}: 297.8843$; found: 297.8854.

\section{(E)-tert-Butyl[(3-iodobut-2-en-1-yl)oxy]dimethylsilane (15)}

To a solution of iodide 21 ( $156 \mathrm{mg}, 0.79 \mathrm{mmol}, 1$ equiv) in dry $\mathrm{CH}_{2} \mathrm{Cl}_{2}$ (3 mL) at $-78{ }^{\circ} \mathrm{C}$ were added dropwise $t$-BuMe ${ }_{2}$ SiOTf $(0.27 \mathrm{~mL}, 1.18$ mmol, 1.5 equiv) and 2,6-lutidine ( $0.27 \mathrm{~mL}, 1.18 \mathrm{mmol}, 3$ equiv) and the resulting mixture was stirred for $1 \mathrm{~h}$. The reaction was quenched with saturated $\mathrm{NaHCO}_{3}$ solution, allowed to warm to r.t. and extracted with $\mathrm{CH}_{2} \mathrm{Cl}_{2}$. The combined organic fractions were dried over $\mathrm{Na}_{2} \mathrm{SO}_{4}$, filtered, and concentrated under reduced pressure. The residue was purified by column chromatography on silica gel (hexane/ $/ \mathrm{Et}_{2} \mathrm{O}, 30: 1$ ) to give $\mathbf{1 5}(236 \mathrm{mg}, 96 \%)$ as a colorless oil.

${ }^{1} \mathrm{H}$ NMR (400 MHz, $\mathrm{CDCl}_{3}$ ): $\delta=6.30$ (tq, $J=6.5,1.5 \mathrm{~Hz}, 1 \mathrm{H}$ ), 4.12 (ddd, $J=6.5,1.8,0.8 \mathrm{~Hz}, 2 \mathrm{H}), 2.41$ (dt, $J=1.6,0.9 \mathrm{~Hz}, 3 \mathrm{H}), 0.90(\mathrm{~s}, 9 \mathrm{H}), 0.07$ (s, $6 \mathrm{H})$.

${ }^{13} \mathrm{C}$ NMR $\left(101 \mathrm{MHz}, \mathrm{CDCl}_{3}\right): \delta=140.80,96.14,60.82,28.23,26.03$, $18.49,-5.06$. 
The data are consistent with those reported in the literature.[51]

(Z)-3-(4,4,5,5-Tetramethyl-1,3,2-dioxaborolan-2-yl)but-2-en-1-ol (16)

The product 16 ( $0.5 \mathrm{~g}, 69 \%$ yield) was obtained from 2-butyn-1-ol (6) (253 $\mathrm{mg}, 3.58 \mathrm{mmol}$ ) according to the literature procedure.[46]

\section{(2Z,4E,6Z,8E)-7-Bromo-10-hydroxy-3,8-dimethyldeca-2,4,6,8-tet- raenenitrile (17)}

To a solution of $\mathbf{1 6}$ ( $56 \mathrm{mg}, 0.28 \mathrm{mmol}, 1.1$ equiv) in degassed THF $(0.45 \mathrm{~mL})$ under an argon atmosphere was added TlOEt $(0.018 \mathrm{~mL}$, $0.25 \mathrm{mmol}, 1$ equiv) followed by $\mathrm{H}_{2} \mathrm{O}(0.04 \mathrm{~mL})$ and the resulting mixture was stirred at r.t. for $5 \mathrm{~min}$. A solution of $\mathbf{1 4}(70 \mathrm{mg}, 0.25 \mathrm{mmol}, 1$ equiv) and $\mathrm{Pd}\left(\mathrm{PPh}_{3}\right)_{4}(15 \mathrm{mg}, 0.013 \mathrm{mmol}, 0.05$ equiv) in THF $(1 \mathrm{~mL})$ was added and the mixture was stirred at r.t. for $4 \mathrm{~h}$. After filtration through a pad of Celite ${ }^{\circledR}$ and $\mathrm{Na}_{2} \mathrm{SO}_{4}$, the filtrate was concentrated under vacuum and the residue purified by column chromatography on $\mathrm{SiO}_{2}$ (hexane/ $\mathrm{Et}_{2} \mathrm{O}, 60: 1$ to $2: 1$ ) to give: (1) dibromide $\mathbf{1 4}$ (22 $\mathrm{mg}, 31 \%$ ), and (2) adduct 17 (43 mg,63\%), which was isolated crude and used in the next step without purification.

(2Z,4E,6Z,8E)-7-Bromo-10-[(tert-butyldimethylsilyl)oxy]-3,8-dimethyldeca-2,4,6,8-tetraenenitrile (18) and $(2 Z, 4 Z, 6 E)-6$-Bromo8-\{[(tert-butyldimethylsilyl)oxy]methyl\}-2,7-dimethylcycloocta2,4,6-triene-1-carbonitrile (19)

A solution of $\mathbf{1 7}$ (40 mg, $0.15 \mathrm{mmol}, 1$ equiv) in $\mathrm{CH}_{2} \mathrm{Cl}_{2}(1.5 \mathrm{~mL})$ was cooled to $-85^{\circ} \mathrm{C}$ under an argon atmosphere and 2,6-lutidine $(0.05$ $\mathrm{mL}, 0.45 \mathrm{mmol}, 3$ equiv) was added, followed by the addition of $t$ BuMe $_{2} \operatorname{SiOTf}(0.05 \mathrm{~mL}, 0.22 \mathrm{mmol}, 1.5$ equiv). The mixture was stirred at this temperature for $1 \mathrm{~h}$ and then quenched by the addition of brine. The mixture was allowed to warm to r.t. and then extracted with $\mathrm{Et}_{2} \mathrm{O}$, dried over $\mathrm{Na}_{2} \mathrm{SO}_{4}$ and concentrated under vacuum. The residue was purified by column chromatography on $\mathrm{SiO}_{2}$ (hexane/ $\mathrm{Et}_{2} \mathrm{O}, 100: 1$ to $\left.35: 1\right)$ to give tetraenenitrile $\mathbf{1 8}(52 \mathrm{mg}, 91 \%)$ and cyclized compound 19 (5 mg, 8\%).

\section{Compound 18}

IR (thin film): 2952, 2929, 2884, 2856, 2209, 1595, 1253, 1105, 1070 , $834,769 \mathrm{~cm}^{-1}$.

$\left.{ }^{1} \mathrm{H} \mathrm{NMR} \mathrm{(400} \mathrm{MHz,} \mathrm{CDCl}_{3}\right): \delta=7.04(\mathrm{dt}, J=29.7,12.5 \mathrm{~Hz}, 2 \mathrm{H}), 6.71(\mathrm{~d}$, $J=9.7 \mathrm{~Hz}, 1 \mathrm{H}), 6.31(\mathrm{t}, J=5.6 \mathrm{~Hz}, 1 \mathrm{H}), 5.20(\mathrm{~d}, J=1.1 \mathrm{~Hz}, 1 \mathrm{H}), 4.40(\mathrm{~d}$, $J=5.9 \mathrm{~Hz}, 2 \mathrm{H}), 2.10(\mathrm{~d}, J=1.4 \mathrm{~Hz}, 3 \mathrm{H}), 1.92(\mathrm{~d}, J=0.9 \mathrm{~Hz}, 3 \mathrm{H}), 0.91(\mathrm{~s}$, $9 \mathrm{H}), 0.09(\mathrm{~s}, 6 \mathrm{H})$.

${ }^{13} \mathrm{C}$ NMR $\left(101 \mathrm{MHz}, \mathrm{CDCl}_{3}\right): \delta=156.17,136.57,135.30,134.05$, 132.80, 132.13, 127.02, 117.05, 97.39, 61.13, 26.05, 19.39, 18.47, $15.39,-5.01$.

HRMS (ESI): $m / z[\mathrm{M}+\mathrm{Na}]^{+}$calcd for $\mathrm{C}_{18} \mathrm{H}_{28} \mathrm{NONaSiBr}$ : 404.1021; found: 404.1035 .

\section{Compound 19}

IR (thin film): 2954, 2929, 2885, 2857, 1471, 1256, 1100, 837, 778 $\mathrm{cm}^{-1}$.

${ }^{1} \mathrm{H}$ NMR $\left(400 \mathrm{MHz}, \mathrm{CDCl}_{3}\right): \delta=6.65(\mathrm{dd}, J=14.1,11.2 \mathrm{~Hz}, 1 \mathrm{H}), 6.28(\mathrm{~d}$, $J=14.0 \mathrm{~Hz}, 1 \mathrm{H}), 6.04(\mathrm{~d}, J=11.1 \mathrm{~Hz}, 1 \mathrm{H}), 4.02(\mathrm{t}, J=9.8 \mathrm{~Hz}, 1 \mathrm{H}), 3.94$ (dd, $J=10.1,5.1 \mathrm{~Hz}, 1 \mathrm{H}), 3.79-3.68(\mathrm{~m}, 2 \mathrm{H}), 2.00(\mathrm{~s}, 6 \mathrm{H}), 0.93$ (s, 9 $\mathrm{H}), 0.14(\mathrm{~s}, 3 \mathrm{H}), 0.13(\mathrm{~s}, 3 \mathrm{H})$.

${ }^{13} \mathrm{C}$ NMR $\left(101 \mathrm{MHz}, \mathrm{CDCl}_{3}\right): \delta=133.75,132.28,131.59,130.21$, 128.69, 127.06, 119.46, 62.33, 50.93, 39.44, 25.99, 19.65, 18.38, 17.21, $-5.19,-5.25$
HRMS (ESI): $m / z[\mathrm{M}+\mathrm{Na}]^{+}$calcd for $\mathrm{C}_{18} \mathrm{H}_{28} \mathrm{NONaSiBr}$ : 404.1021; found: 404.1031 .

(2Z,4E,6E,8E)-10-[(tert-Butyldimethylsilyl)oxy]-3,7,8-trimethyldeca-2,4,6,8-tetraenenitrile (20)

To solution of $\operatorname{Pd}\left(t-\mathrm{Bu}_{3} \mathrm{P}\right)_{2}$ ( $4 \mathrm{mg}, 0.008 \mathrm{mmol}, 0.1$ equiv) in THF $(0.4$ $\mathrm{mL})$ at $0{ }^{\circ} \mathrm{C}$ was added $\mathrm{ZnMe}_{2}(0.16 \mathrm{~mL}, 0.32 \mathrm{~mL}, 4$ equiv). The obtained solution was transferred via cannula to neat $\mathbf{1 8}(31 \mathrm{mg}, 0.08$ mmol, 1 equiv) which had been cooled to $0{ }^{\circ} \mathrm{C}$ under argon. The resulting mixture was stirred at $0{ }^{\circ} \mathrm{C}$ for $4 \mathrm{~h}$ and then quenched with a saturated aqueous solution of $\mathrm{NaHCO}_{3}$ and extracted with $\mathrm{CH}_{2} \mathrm{Cl}_{2}$. The combined organic fractions were dried over $\mathrm{Na}_{2} \mathrm{SO}_{4}$ and concentrated under vacuum. The residue was purified by column chromatography on $\mathrm{SiO}_{2}$ (hexane/Et ${ }_{2} \mathrm{O}, 60: 1$ to $40: 1$ ) to give $\mathbf{2 0}$ (11 mg, 42\%).

IR (thin film): 2954, 2929, 2856, 2209, 1593, 1255, 1094, 1050, 960, $836 \mathrm{~cm}^{-1}$.

${ }^{1} \mathrm{H}$ NMR $\left(400 \mathrm{MHz}, \mathrm{CDCl}_{3}\right): \delta=6.99(\mathrm{dd}, J=15.0,11.0 \mathrm{~Hz}, 1 \mathrm{H}), 6.85(\mathrm{~d}$, $J=15.0 \mathrm{~Hz}, 1 \mathrm{H}), 6.38(\mathrm{~d}, J=11.0 \mathrm{~Hz}, 1 \mathrm{H}), 5.86(\mathrm{t}, J=5.6 \mathrm{~Hz}, 1 \mathrm{H}), 5.09$ $(\mathrm{s}, 1 \mathrm{H}), 4.40(\mathrm{~d}, J=5.8 \mathrm{~Hz}, 2 \mathrm{H}), 2.07(\mathrm{~d}, J=1.3 \mathrm{~Hz}, 3 \mathrm{H}), 2.02(\mathrm{~s}, 3 \mathrm{H})$, $1.84(\mathrm{~d}, J=0.8 \mathrm{~Hz}, 3 \mathrm{H}), 0.92(\mathrm{~s}, 9 \mathrm{H}), 0.09(\mathrm{~s}, 6 \mathrm{H})$.

${ }^{13} \mathrm{C}$ NMR $\left(101 \mathrm{MHz}, \mathrm{CDCl}_{3}\right): \delta=156.64,143.16,135.98,133.59$, $130.57,129.45,125.30,117.50,95.44,61.43,26.13,19.57,18.56$, $14.69,14.31,-4.95$.

HRMS (ESI): $m / z$ [M + Na $]^{+}$calcd for $\mathrm{C}_{19} \mathrm{H}_{31} \mathrm{NONaSi}$ : 340.2073; found: 340.2077 .

\section{(E)-3-Iodobut-2-en-1-ol (21)}

Under argon at $0{ }^{\circ} \mathrm{C}$, DIBAL-H $(4.28 \mathrm{~mL}, 1 \mathrm{M}$ in hexane, $4.28 \mathrm{mmol}, 1$ equiv) was added slowly via syringe to a solution of but-2-yn-1-ol (6) (300 mg, $4.28 \mathrm{mmol}, 1$ equiv) in THF (0.3 mL) and the solution was then allowed to warm to r.t. and stirred for $1 \mathrm{~h}$. To another flask covered with aluminum foil under argon were added $\mathrm{Cp}_{2} \mathrm{ZrCl}_{2}(2.5 \mathrm{~g}, 8.56$ mmol, 2 equiv) and THF (15 mL). To this suspension was added dropwise DIBAL-H ( $8.6 \mathrm{~mL}, 1 \mathrm{M}$ in hexane, $8.6 \mathrm{mmol}, 2$ equiv) at $0{ }^{\circ} \mathrm{C}$. After $30 \mathrm{~min}$, the pretreated alcohol mixture was transferred via cannula into the second reaction flask and the resulting mixture was stirred at $40{ }^{\circ} \mathrm{C}$ for $3.5 \mathrm{~h}$ until all the solid had dissolved. Next, the mixture was cooled to $0{ }^{\circ} \mathrm{C}$ and treated with a solution of $\mathrm{I}_{2}(2.4 \mathrm{~g}, 9.42 \mathrm{mmol}, 2.2$ equiv) in THF ( $5 \mathrm{~mL})$. After stirring at $0{ }^{\circ} \mathrm{C}$ for $15 \mathrm{~min}$, the mixture was diluted with $\mathrm{Et}_{2} \mathrm{O}$ and quenched with saturated $\mathrm{Na}_{2} \mathrm{~S}_{2} \mathrm{O}_{3}$ solution. The mixture was extracted with $\mathrm{Et}_{2} \mathrm{O}$ and the combined organic layers were dried over $\mathrm{Na}_{2} \mathrm{SO}_{4}$ and concentrated under reduced pressure. The residue was purified by column chromatography on $\mathrm{SiO}_{2}$ (hexane/ $\mathrm{Et}_{2} \mathrm{O}, 40: 1$ to 3:1) to give $\mathbf{2 1}$ (402 $\mathrm{mg}, 47 \%$ ).

${ }^{1} \mathrm{H} \mathrm{NMR}\left(400 \mathrm{MHz}, \mathrm{CDCl}_{3}\right): \delta=6.44-6.38(\mathrm{~m}, 1 \mathrm{H}), 4.09(\mathrm{t}, J=6.0 \mathrm{~Hz}, 2$ H), $2.45(\mathrm{~d}, J=0.7 \mathrm{~Hz}, 3 \mathrm{H}), 1.46$ (br s, $1 \mathrm{H})$.

${ }^{13} \mathrm{C} \mathrm{NMR}\left(101 \mathrm{MHz}, \mathrm{CDCl}_{3}\right): \delta=139.85,98.71,60.10,28.16$.

The data are consistent with those reported in the literature. ${ }^{52}$

\section{3-Hydroxy-2-methylpentanal (24)}

The product was obtained by the 4-trans-hydroxy-L-proline-catalyzed aldol reaction of propionaldehyde in DMSO at $4{ }^{\circ} \mathrm{C} .40$

\section{3-[(tert-Butyldimethylsilyl)oxy]-2-methylpentanal (25)}

To a solution of aldehyde $\mathbf{2 4}(0.5 \mathrm{~g}, 4.3 \mathrm{mmol})$ and DIPEA (3.2 mL, 18.4 $\mathrm{mmol})$ in dry $\mathrm{CH}_{2} \mathrm{Cl}_{2}(20 \mathrm{~mL})$ cooled to $-5^{\circ} \mathrm{C}$ was added $t$-BuMe${ }_{2} \mathrm{SiOTf}$ ( $3 \mathrm{~mL}, 13.1 \mathrm{mmol}$ ) dropwise and stirring was continued for $1 \mathrm{~h}$. During this time the temperature rose to $0{ }^{\circ} \mathrm{C}$, and at this point the reaction was quenched with saturated $\mathrm{NaHCO}_{3}$ solution and extracted 
with $\mathrm{CH}_{2} \mathrm{Cl}_{2}$. The combined organic fractions were dried over $\mathrm{Na}_{2} \mathrm{SO}_{4}$, filtered, and concentrated under reduced pressure without heating. The residue was purified by column chromatography on silica gel (hexane/ $\mathrm{Et}_{2} \mathrm{O}, 40: 1$ to $\left.16: 1\right)$ to give $\mathbf{2 5}(0.97 \mathrm{~g}, 98 \%)$ as a colorless oil. IR (thin film): 2958, 2931, 2858, 1726, 1463, 1253, 833, 773, $668 \mathrm{~cm}^{-1}$. ${ }^{1} \mathrm{H} \mathrm{NMR}\left(400 \mathrm{MHz}, \mathrm{CDCl}_{3}\right): \delta=9.74(\mathrm{dd}, J=7.3,1.7 \mathrm{~Hz}, 1 \mathrm{H}), 4.02(\mathrm{td}$, $J=6.6,3.7 \mathrm{~Hz}, 0.5 \mathrm{H}), 3.85(\mathrm{q}, J=5.5 \mathrm{~Hz}, 0.5 \mathrm{H}), 2.55-2.40(\mathrm{~m}, 1 \mathrm{H})$, 1.63-1.42 (m, $2 \mathrm{H}), 1.05(\mathrm{~d}, J=7.0 \mathrm{~Hz}, 1.5 \mathrm{H}), 1.04(\mathrm{~d}, J=6.9 \mathrm{~Hz}, 1.5 \mathrm{H})$, 0.92-0.87 (m, $3 \mathrm{H}), 0.86(\mathrm{~s}, 4.5 \mathrm{H}), 0.85(\mathrm{~s}, 4.5 \mathrm{H}), 0.05(\mathrm{~s}, 3 \mathrm{H}), 0.04$ (s, $1.5 \mathrm{H}), 0.02(\mathrm{~s}, 1.5 \mathrm{H})$.

${ }^{13} \mathrm{C}$ NMR (101 $\mathrm{MHz}, \mathrm{CDCl}_{3}$ ): $\delta=205.50,205.27,74.65,73.49,50.93$, $50.71,27.58,27.53,25.89,25.88,18.16,18.14,10.61,10.22,9.03,7.66$, $-4.11,-4.16,-4.68$.

\section{tert-Butyl[(6,6-dibromo-4-methylhex-5-en-3-yl)oxy]dimethylsi- lane (anti-26) and tert-Butyl[(6,6-dibromo-4-methylhex-5-en-3- yl)oxy]dimethylsilane (syn-27)}

To a solution of $\mathrm{Ph}_{3} \mathrm{P}(11.4 \mathrm{~g}, 43.4 \mathrm{mmol})$ in dry $\mathrm{CH}_{2} \mathrm{Cl}_{2}(40 \mathrm{~mL})$ cooled to $-15{ }^{\circ} \mathrm{C}$ under an inert atmosphere was added a solution of $\mathrm{CBr}_{4}$ ( $1.55 \mathrm{~g}, 21.7 \mathrm{mmol}, 5.6$ equiv) in dry $\mathrm{CH}_{2} \mathrm{Cl}_{2}(5 \mathrm{~mL})$. After $5 \mathrm{~min}$, the reaction mixture turned yellow and a solution of aldehyde $\mathbf{2 5}(0.9 \mathrm{~g}$, $3.9 \mathrm{mmol})$ in dry $\mathrm{CH}_{2} \mathrm{Cl}_{2}(5 \mathrm{~mL})$ was added dropwise. Over the next 2 $\mathrm{h}$ the mixture was allowed to warm to r.t. until the reaction was complete. Hexane was added and the obtained precipitate was removed by filtration. The filtrate was concentrated under vacuum and the residue was purified by column chromatography on silica gel (hexane) to give a mixture of two diastereomers 26 and $\mathbf{2 7}(1.00 \mathrm{~g}, 67 \%)$ as a colorless oil. These two diastereomers were partly separated by consecutive column chromatography on silica gel (hexane) to give the individual diastereomers.

\section{anti-26}

IR (thin film): 2958, 2930, 2857, 1461, 1255, 1109, 1079, 1038, 872, $834,773 \mathrm{~cm}^{-1}$.

${ }^{1} \mathrm{H}$ NMR $\left(400 \mathrm{MHz}, \mathrm{CDCl}_{3}\right): \delta=6.37(\mathrm{~d}, J=9.5 \mathrm{~Hz}, 1 \mathrm{H}), 3.49$ (ddd, $J=$ 6.7, 5.9, $3.5 \mathrm{~Hz}, 1 \mathrm{H}), 2.61(\mathrm{~m}, 1 \mathrm{H}), 1.51-1.31(\mathrm{~m}, 2 \mathrm{H}), 1.01$ (d, $J=6.9$ $\mathrm{Hz}, 3 \mathrm{H}), 0.90(\mathrm{~s}, 9 \mathrm{H}), 0.87(\mathrm{t}, J=7.5 \mathrm{~Hz}, 3 \mathrm{H}), 0.06(\mathrm{~s}, 3 \mathrm{H}), 0.05(\mathrm{~s}, 3$ $\mathrm{H})$.

${ }^{13} \mathrm{C}$ NMR $\left(101 \mathrm{MHz}, \mathrm{CDCl}_{3}\right): \delta=140.96,88.04,76.27,42.86,28.14$, $26.05,18.25,15.97,10.01,-4.06,-4.38$.

HRMS (ESI): $m / z[\mathrm{M}+\mathrm{Na}]^{+}$calcd for $\mathrm{C}_{13} \mathrm{H}_{26} \mathrm{ONaSiBr}_{2}: 407.0017$; found: 407.0003.

\section{syn-27}

IR (thin film): 2957, 2929, 2857, 1462, 1377, 1255, 1014, 873, 833 , 773.

${ }^{1} \mathrm{H}$ NMR $\left(400 \mathrm{MHz}, \mathrm{CDCl}_{3}\right): \delta=6.32(\mathrm{~d}, J=9.5 \mathrm{~Hz}, 1 \mathrm{H}), 3.56(\mathrm{dd}, J=$ $11.1,5.5 \mathrm{~Hz}, 1 \mathrm{H}), 2.64-2.49(\mathrm{~m}, 1 \mathrm{H}), 1.58-1.37$ (m, $2 \mathrm{H}), 0.97$ (d, $J=$ $6.8 \mathrm{~Hz}, 3 \mathrm{H}), 0.90$ (s, $9 \mathrm{H}), 0.88$ (m, $3 \mathrm{H}), 0.05$ (s, $3 \mathrm{H}), 0.05$ (s, $3 \mathrm{H})$.

${ }^{13} \mathrm{C}$ NMR $\left(101 \mathrm{MHz}, \mathrm{CDCl}_{3}\right): \delta=142.65,87.58,75.45,42.37,27.64$, $26.03,18.27,13.25,9.63,-4.09,-4.50$.

HRMS (ESI): $m / z[\mathrm{M}+\mathrm{Na}]^{+}$calcd for $\mathrm{C}_{13} \mathrm{H}_{26} \mathrm{ONaSiBr}_{2}: 407.0017$; found: 407.0000 .

\section{tert-Butyldimethyl $\{[(3 S, 4 R)-4$-methylhept-5-yn-3-yl $]$ oxy $\}$ silane} (28)

To a solution of dibromide $\mathbf{2 6}(0.4 \mathrm{~g}, 1.0 \mathrm{mmol})$ in THF ( $5 \mathrm{~mL})$ at $-78{ }^{\circ} \mathrm{C}$ was added $n$-BuLi $(1.66 \mathrm{~mL}, 2 \mathrm{M}$ in hexane, $3.3 \mathrm{mmol}, 3.3$ equiv) dropwise. The reaction mixture was allowed to warm to $-50{ }^{\circ} \mathrm{C}$ over 20 min at which point TLC indicated that no dibromide $\mathbf{2 6}$ remained. The mixture was cooled to $-78{ }^{\circ} \mathrm{C}$ and $\mathrm{MeI}(0.2 \mathrm{~mL}, 3.1 \mathrm{mmol}$, 3.1 equiv) was added dropwise. The mixture was allowed to warm to $-45^{\circ} \mathrm{C}$ over $15 \mathrm{~min}$ at which point the reaction was complete. The cooling bath was removed and the mixture was allowed to warm to r.t., poured into saturated $\mathrm{NH}_{4} \mathrm{Cl}$ solution and extracted with $\mathrm{CH}_{2} \mathrm{Cl}_{2}$. The combined organic fractions were dried over $\mathrm{Na}_{2} \mathrm{SO}_{4}$, filtered, and concentrated under reduced pressure without heating. The residue was purified by column chromatography on silica gel ( $\left.\mathrm{PE} / \mathrm{Et}_{2} \mathrm{O}, 90: 1\right)$ to give $\mathbf{2 8}$ (230 $\mathrm{mg}, 92 \%$ ).

IR (thin film): 2958, 2930, 2857, 1253, 1107, 1063, 871, 832, $771 \mathrm{~cm}^{-1}$. ${ }^{1} \mathrm{H} \mathrm{NMR}\left(400 \mathrm{MHz}, \mathrm{CDCl}_{3}\right): \delta=3.56(\mathrm{dt}, J=8.2,4.1 \mathrm{~Hz}, 1 \mathrm{H}), 2.49-2.57$ $(\mathrm{m}, 1 \mathrm{H}), 1.78(\mathrm{~d}, J=2.4 \mathrm{~Hz}, 3 \mathrm{H}), 1.72-1.60(\mathrm{~m}, 1 \mathrm{H}), 1.47-1.35(\mathrm{~m}, 1$ $\mathrm{H}), 1.08(\mathrm{~d}, J=7.1 \mathrm{~Hz}, 3 \mathrm{H}), 0.95-0.84(\mathrm{~m}, 12 \mathrm{H}), 0.05(\mathrm{~s}, 6 \mathrm{H})$.

${ }^{13} \mathrm{C}$ NMR $\left(101 \mathrm{MHz}, \mathrm{CDCl}_{3}\right): \delta=81.79,76.82,76.35,32.25,26.02$, $25.61,18.28,15.30,10.63,3.70,-4.35$.

HRMS (ESI): $m / z$ [M $+\mathrm{Na}]^{+}$calcd for $\mathrm{C}_{14} \mathrm{H}_{28} \mathrm{ONaSi}$ : 263.1807; found: 263.1795 .

tert-Butyl $\{[(3 S, 4 R, E)-6$-iodo-4-methylhept-5-en-3-yl]oxy\}dimethylsilane (29)

Under argon at $0{ }^{\circ} \mathrm{C}$, DIBAL-H $(0.07 \mathrm{~mL}, 1 \mathrm{M}$ in cyclohexane, 0.07 mmol, 0.3 equiv) was added slowly via syringe to a solution of $\mathbf{2 8}$ (60 $\mathrm{mg}, 0.25 \mathrm{mmol}, 1$ equiv) in THF ( $1 \mathrm{~mL})$. The solution was allowed to warm to r.t. and stirred for $1 \mathrm{~h}$. To another flask covered with aluminum foil under argon were added $\mathrm{Cp}_{2} \mathrm{ZrCl}_{2}(182 \mathrm{mg}, 0.62 \mathrm{mmol}, 2.5$ equiv) and THF $(1.5 \mathrm{~mL})$. To this suspension was added dropwise DIBAL-H ( $0.62 \mathrm{~mL}, 1 \mathrm{M}$ in cyclohexane, $0.62 \mathrm{mmol}, 2.5$ equiv) at $0{ }^{\circ} \mathrm{C}$. After $50 \mathrm{~min}$, the pretreated solution of $\mathbf{2 8}$ was transferred via cannula into the second reaction flask, the cooling bath was removed and the mixture was allowed to warm to r.t. and then stirred at $40{ }^{\circ} \mathrm{C}$ for 1 $\mathrm{h}$ until all the solid had dissolved. The mixture was cooled to $-78{ }^{\circ} \mathrm{C}$ and treated with a solution of $\mathrm{I}_{2}(158 \mathrm{mg}, 0.62 \mathrm{mmol}, 2.5$ equiv) in THF ( $1 \mathrm{~mL})$ until the iodine color was persistent. After $5 \mathrm{~min}$, the cooling bath was removed, and the mixture was allowed to warm to r.t. and then quenched with a minimum amount of aqueous $\mathrm{Na}_{2} \mathrm{~S}_{2} \mathrm{O}_{3}$ solution, dried over $\mathrm{Na}_{2} \mathrm{SO}_{4}$ and filtered through a Celite ${ }^{\circledR}$ pad. The pad was rinsed with $\mathrm{Et}_{2} \mathrm{O}$ and the filtrate was concentrated under vacuum. The residue was purified by column chromatography on silica gel (hexane) to give $\mathbf{2 9}$ (60 $\mathrm{mg}, 65 \%$ ) as a colorless oil.

IR (thin film): 2958, 2929, 2856, 1377, 1251, 1023, 1005, 832, 772 $\mathrm{cm}^{-1}$.

${ }^{1} \mathrm{H}$ NMR $\left(400 \mathrm{MHz}, \mathrm{CDCl}_{3}\right): \delta=6.07(\mathrm{~d}, J=10.0 \mathrm{~Hz}, 1 \mathrm{H}), 3.37-3.45(\mathrm{~m}$, $1 \mathrm{H}), 2.57-2.46(\mathrm{~m}, 1 \mathrm{H}), 2.38(\mathrm{~d}, J=1.4 \mathrm{~Hz}, 3 \mathrm{H}), 1.50-1.37(\mathrm{~m}, 2 \mathrm{H})$, $0.94(\mathrm{~d}, J=6.9 \mathrm{~Hz}, 3 \mathrm{H}), 0.89(\mathrm{~s}, 9 \mathrm{H}), 0.84(\mathrm{t}, J=7.4 \mathrm{~Hz}, 3 \mathrm{H}), 0.05$ (s, 3 $\mathrm{H}), 0.04(\mathrm{~s}, 3 \mathrm{H})$.

${ }^{13} \mathrm{C}$ NMR $\left(101 \mathrm{MHz}, \mathrm{CDCl}_{3}\right): \delta=144.09,93.64,76.49,40.12,28.01$, $27.28,26.06,18.24,16.60,9.61,-4.15,-4.26$.

HRMS (ESI): $m / z$ [M $+\mathrm{Na}]^{+}$calcd for $\mathrm{C}_{14} \mathrm{H}_{29} \mathrm{ONaSiI}$ : 391.0930; found: 391.0919 .

\section{(2E,4E,6R,7S)-7-[(tert-Butyldimethylsilyl)oxy]-3,4,6-trimethylno- na-2,4-dien-1-ol (38)}

To a solution of boronic ether $\mathbf{1 6}$ ( $163 \mathrm{mg}, 0.81 \mathrm{mmol}, 2$ equiv) in THF $(1.5 \mathrm{~mL})$ under argon was added TlOEt $(0.05 \mathrm{~mL}, 0.73 \mathrm{mmol}, 1.8$ equiv) and degassed $\mathrm{H}_{2} \mathrm{O}(0.15 \mathrm{~mL})$ at r.t. and the resulting mixture was stirred for $5 \mathrm{~min}$. To this mixture were added a solution of iodide 29 (150 mg, $0.41 \mathrm{mmol}, 1$ equiv) in THF $(0.6 \mathrm{~mL})$ and $\mathrm{Pd}\left(\mathrm{PPh}_{3}\right)_{4}(23$ $\mathrm{mg}, 0.02 \mathrm{mmol}, 0.05$ equiv) and stirring was continued for $4 \mathrm{~h}$. The mixture was filtered through Celite ${ }^{\circledR}$ and the pad rinsed with $\mathrm{Et}_{2} \mathrm{O}$. 
The filtrate was concentrated under vacuum and the residue purified by column chromatography on silica gel (hexane/ $\mathrm{Et}_{2} \mathrm{O}, 30: 1$ to $6: 1$ ) to give adduct 38 (161 $\mathrm{mg}, 95 \%)$ as a colorless oil.

IR (thin film): 3314, 2957, 2929, 2857, 1462, 1377, 1254, 1102, 1073 , $1060,1006,835,773 \mathrm{~cm}^{-1}$.

${ }^{1} \mathrm{H}$ NMR $\left(400 \mathrm{MHz}, \mathrm{CDCl}_{3}\right): \delta=5.70(\mathrm{t}, J=6.3 \mathrm{~Hz}, 1 \mathrm{H}), 5.59(\mathrm{~d}, J=9.5$ $\mathrm{Hz}, 1 \mathrm{H}), 4.31(\mathrm{t}, J=6.0 \mathrm{~Hz}, 2 \mathrm{H}), 3.47(\mathrm{td}, J=6.1,3.9 \mathrm{~Hz}, 1 \mathrm{H}), 2.64$ (dqd, $J=13.6,6.8,3.9 \mathrm{~Hz}, 1 \mathrm{H}), 1.83(\mathrm{~s}, 3 \mathrm{H}), 1.81(\mathrm{~d}, J=1.1 \mathrm{~Hz}, 3 \mathrm{H})$, $1.32-1.50(\mathrm{~m}, 2 \mathrm{H}), 1.22(\mathrm{t}, J=5.5 \mathrm{~Hz}, 1 \mathrm{H}), 0.97(\mathrm{~d}, J=6.9 \mathrm{~Hz}, 3 \mathrm{H})$, 0.90 (s, $9 \mathrm{H}), 0.84$ (t, J = 7.4 Hz, $3 \mathrm{H}), 0.04(\mathrm{~s}, 6 \mathrm{H})$.

${ }^{13} \mathrm{C}$ NMR $\left(101 \mathrm{MHz}, \mathrm{CDCl}_{3}\right): \delta=139.64,135.02,130.75,124.05,77.36$, $60.29,37.74,27.24,26.07,18.28,16.98,14.40,14.27,10.27,-4.09$, -4.32 .

HRMS (ESI): $m / z$ [M + Na] $]^{+}$calcd for $\mathrm{C}_{18} \mathrm{H}_{36} \mathrm{O}_{2} \mathrm{NaSi}$ : 335.2382; found: 335.2377 .

\section{(2E,4E,6R,7S)-7-[(tert-Butyldimethylsilyl)oxy]-3,4,6-trimethylno- na-2,4-dienal (39)}

To a solution of alcohol 38 (96 mg, $0.31 \mathrm{mmol})$ in $\mathrm{CH}_{2} \mathrm{Cl}_{2}(15 \mathrm{~mL})$ was added $\mathrm{MnO}_{2}$ (0.5 g, $6.15 \mathrm{mmol}, 20$ equiv) portionwise. The reaction was complete after stirring at r.t. for $1 \mathrm{~h}$. The $\mathrm{MnO}_{2}$ was removed by filtration through a pad of Celite ${ }^{\circledR}$ and the pad was rinsed with $\mathrm{CH}_{2} \mathrm{Cl}_{2}$. The filtrate was concentrated under reduced pressure and the obtained aldehyde 39 (91 mg, 96\%) was used in the next step without purification.

IR (thin film): 2958, 2930, 2857, 1667, 1462, 1378, 1253, 1154, 1078, $1031,836,774 \mathrm{~cm}^{-1}$.

${ }^{1} \mathrm{H} \mathrm{NMR}\left(400 \mathrm{MHz}, \mathrm{CDCl}_{3}\right): \delta=10.15(\mathrm{~d}, J=7.9 \mathrm{~Hz}, 1 \mathrm{H}), 6.11(\mathrm{dd}, J=$ $27.0,8.4 \mathrm{~Hz}, 2 \mathrm{H}), 3.51(\mathrm{td}, J=6.0,3.9 \mathrm{~Hz}, 1 \mathrm{H}), 2.71$ (dqd, $J=13.6,6.8$, $3.8 \mathrm{~Hz}, 1 \mathrm{H}), 2.30(\mathrm{~d}, J=0.8 \mathrm{~Hz}, 3 \mathrm{H}), 1.85(\mathrm{~d}, J=1.1 \mathrm{~Hz}, 3 \mathrm{H}), 1.54-1.29$ $(\mathrm{m}, 2 \mathrm{H}), 1.00(\mathrm{~d}, J=6.9 \mathrm{~Hz}, 3 \mathrm{H}), 0.89(\mathrm{~s}, 9 \mathrm{H}), 0.84(\mathrm{t}, J=7.5 \mathrm{~Hz}, 3 \mathrm{H})$, $0.04(\mathrm{~d}, J=3.0 \mathrm{~Hz}, 6 \mathrm{H})$.

${ }^{13} \mathrm{C}$ NMR $\left(101 \mathrm{MHz}, \mathrm{CDCl}_{3}\right): \delta=192.36,158.48,138.31,135.10$, 125.68, 77.11, 37.90, 27.95, 26.02, 18.23, 17.10, 14.43, 14.28, 9.88, $-4.05,-4.39$.

\section{tert-Butyldimethyl $\{[(3 S, 4 R, 5 E, 7 E)-4,6,7-t r i m e t h y l d e c a-5,7,9-$ trien-3-yl]oxy\}silane (40)}

To a solution of $\mathrm{Ph}_{3} \mathrm{PCH}_{3} \mathrm{I}$ ( $250 \mathrm{mg}, 0.61 \mathrm{mmol}, 2$ equiv) in THF ( $2 \mathrm{~mL}$ ) at $0{ }^{\circ} \mathrm{C}$ under argon was added $\mathrm{NaN}\left(\mathrm{SiMe}_{3}\right)_{2}(0.55 \mathrm{~mL}, 1 \mathrm{M}$ in THF, 0.55 mmol, 1.8 equiv). After stirring for $20 \mathrm{~min}$, a solution of aldehyde 39 (91 $\mathrm{mg}, 0.31 \mathrm{mmol}, 1$ equiv) in THF $(1 \mathrm{~mL})$ was added to the obtained yellow solution and stirring was continued for $2 \mathrm{~h}$. After the reaction was complete, it was quenched by the addition of hexane and evaporated under vacuum until dry. The residue was purified by column chromatography on silica gel (hexane/ $\mathrm{Et}_{2} \mathrm{O}, 90: 1$ ) to give adduct $\mathbf{4 0}$ (76 mg, 84\%) as a colorless oil.

IR (thin film): 2957, 2929, 2857, 1462, 1378, 1252, 1102, 1059, 1005 , $833,772 \mathrm{~cm}^{-1}$.

${ }^{1} \mathrm{H}$ NMR $\left(400 \mathrm{MHz}, \mathrm{CDCl}_{3}\right): \delta=6.74$ (ddd, $J=16.7,10.9,10.1 \mathrm{~Hz}, 1 \mathrm{H}$ ), $6.18(\mathrm{~d}, J=11.0 \mathrm{~Hz}, 1 \mathrm{H}), 5.68-5.60(\mathrm{~m}, 1 \mathrm{H}), 5.23(\mathrm{dd}, J=16.7,1.8 \mathrm{~Hz}$, $1 \mathrm{H}), 5.09$ (dd, $J=10.1,1.9 \mathrm{~Hz}, 1 \mathrm{H}), 3.48(\mathrm{td}, J=6.1,3.9 \mathrm{~Hz}, 1 \mathrm{H}), 2.66$ (dqd, $J=13.6,6.8,3.9 \mathrm{~Hz}, 1 \mathrm{H}), 1.92(\mathrm{~s}, 3 \mathrm{H}), 1.84(\mathrm{~d}, J=1.1 \mathrm{~Hz}, 3 \mathrm{H})$, $1.50-1.33(\mathrm{~m}, 2 \mathrm{H}), 0.97(\mathrm{~d}, J=6.8 \mathrm{~Hz}, 3 \mathrm{H}), 0.90(\mathrm{~s}, 9 \mathrm{H}), 0.84(\mathrm{t}, J=7.4$ $\mathrm{Hz}, 3 \mathrm{H}), 0.05(\mathrm{~d}, J=1.0 \mathrm{~Hz}, 6 \mathrm{H})$.

${ }^{13} \mathrm{C}$ NMR $\left(101 \mathrm{MHz}, \mathrm{CDCl}_{3}\right): \delta=138.79,135.34,134.19,131.25$, 125.58, 116.56, 77.40, 37.92, 27.23, 26.07, 18.29, 16.98, 14.41, 14.36, $10.27,-4.09,-4.31$.
HRMS (ESI): $m / z$ [M $+\mathrm{Na}]^{+}$calcd for $\mathrm{C}_{19} \mathrm{H}_{36} \mathrm{ONaSi}$ : 331.2433; found: 331.2448 .

tert-Butyldimethyl $\{[(3 S, 4 R, 5 E, 7 E, 9 E)-4,6,7-t r i m e t h y l-10-(4,4,5,5-$ tetramethyl-1,3,2-dioxaborolan-2-yl)deca-5,7,9-trien-3-yl]oxy\}silane (45)

A mixture of $\mathbf{4 0}$ (54 mg, $0.17 \mathrm{mmol}, 1$ equiv), 4,4,5,5-tetramethyl-2vinyl-1,3,2-dioxaborolane ( $0.059 \mathrm{~mL}, 0.35 \mathrm{mmol}, 2$ equiv) and Hoveyda-Grubbs $1^{\text {st }}$ generation catalyst $(16 \mathrm{mg}, 0.03 \mathrm{mmol}, 0.15$ equiv) in $\mathrm{CH}_{2} \mathrm{Cl}_{2}(0.7 \mathrm{~mL})$ was heated at $35-40{ }^{\circ} \mathrm{C}$ with stirring under argon for $3 \mathrm{~h}$. After completion, the reaction was loaded onto a silica gel column and eluted with hexane/ $\mathrm{Et}_{2} \mathrm{O}$ (50:1 to $35: 1$ ) to give adduct 45 (55 mg, $72 \%)$

IR (thin film): 2976, 2958, 2930, 2857, 1606, 1379, 1350, 1257, 1143 , $850 \mathrm{~cm}^{-1}$.

${ }^{1} \mathrm{H}$ NMR $\left(400 \mathrm{MHz}, \mathrm{CDCl}_{3}\right): \delta=7.43(\mathrm{dd}, J=17.3,11.0 \mathrm{~Hz}, 1 \mathrm{H}), 6.24(\mathrm{~d}$, $J=10.9 \mathrm{~Hz}, 1 \mathrm{H}), 5.71(\mathrm{~d}, J=9.0 \mathrm{~Hz}, 1 \mathrm{H}), 5.56(\mathrm{~d}, J=17.3 \mathrm{~Hz}, 1 \mathrm{H}), 3.48$ $(\mathrm{td}, J=5.9,4.1 \mathrm{~Hz}, 1 \mathrm{H}), 2.67(\mathrm{dqd}, J=13.6,6.8,4.1 \mathrm{~Hz}, 1 \mathrm{H}), 1.99(\mathrm{~d}, J=$ $0.6 \mathrm{~Hz}, 3 \mathrm{H}), 1.83(\mathrm{~d}, J=1.0 \mathrm{~Hz}, 3 \mathrm{H}), 1.41(\mathrm{~m}, 2 \mathrm{H}), 1.28(\mathrm{~s}, 12 \mathrm{H}), 0.97$ $(\mathrm{d}, J=6.8 \mathrm{~Hz}, 3 \mathrm{H}), 0.89(\mathrm{~s}, 9 \mathrm{H}), 0.84(\mathrm{t}, J=7.4 \mathrm{~Hz}, 3 \mathrm{H}), 0.04(\mathrm{~s}, 6 \mathrm{H})$.

${ }^{13} \mathrm{C}$ NMR $\left(101 \mathrm{MHz}, \mathrm{CDCl}_{3}\right): \delta=146.75,142.34,135.50,132.72$, $127.13,83.20,77.32,38.00,27.25,26.06,24.92,18.27,16.92,14.81$, $14.41,10.16,-4.10,-4.32$.

HRMS (ESI): $m / z$ [M + Na $]^{+}$calcd for $\mathrm{C}_{25} \mathrm{H}_{47} \mathrm{O}_{3} \mathrm{NaSiB}: 457.3285$; found: 457.3282 .

(2Z,4E,6E,8E,10R,11S)-11-[(tert-Butyldimethylsilyl)oxy]-3,7,8,10tetramethyltrideca-2,4,6,8-tetraenenitrile (41)

To a solution of boronic ether $\mathbf{4 5}$ ( $27 \mathrm{mg}, 0.06 \mathrm{mmol}, 1$ equiv) in THF $(0.9 \mathrm{~mL})$ under argon was added TlOEt $(0.01 \mathrm{~mL}, 0.14 \mathrm{mmol}, 2.3$ equiv) and degassed $\mathrm{H}_{2} \mathrm{O}(0.09 \mathrm{~mL})$ at r.t. and the mixture stirred for 5 min. Next, a solution of iodide $\mathbf{1}$ ( $16 \mathrm{mg}, 0.08 \mathrm{mmol}, 1.4$ equiv) in THF $(1 \mathrm{~mL})$ and $\mathrm{Pd}\left(\mathrm{PPh}_{3}\right)_{4}(7 \mathrm{mg}, 0.006 \mathrm{mmol}, 0.1$ equiv) were added and stirring was continued for $1 \mathrm{~h}$. The reaction mixture was filtered through Celite ${ }^{\circledR}$ and the pad was rinsed with $\mathrm{Et}_{2} \mathrm{O}$. The filtrate was concentrated under vacuum. The residue was purified by column chromatography on silica gel (hexane/ $\mathrm{Et}_{2} \mathrm{O}, 100: 1$ to 80:1) to give adduct 41 (15 mg, 67\%) as a colorless oil.

IR (thin film): 2957, 2929, 2856, 2209, 1591, 1378, 1360, 1252, 1078, $1029,961,835,773 \mathrm{~cm}^{-1}$.

${ }^{1} \mathrm{H} \mathrm{NMR}\left(400 \mathrm{MHz}, \mathrm{CDCl}_{3}\right): \delta=7.00(\mathrm{dd}, J=15.0,11.1 \mathrm{~Hz}, 1 \mathrm{H}), 6.84(\mathrm{~d}$, $J=15.0 \mathrm{~Hz}, 1 \mathrm{H}), 6.35(\mathrm{~d}, J=11.1 \mathrm{~Hz}, 1 \mathrm{H}), 5.79(\mathrm{~d}, J=9.5 \mathrm{~Hz}, 1 \mathrm{H}), 5.07$ $(\mathrm{s}, 1 \mathrm{H}), 3.50(\mathrm{td}, J=6.0,3.9 \mathrm{~Hz}, 1 \mathrm{H}), 2.69(\mathrm{dqd}, J=13.6,6.8,3.9 \mathrm{~Hz}, 1$ H), 2.07 (d, $J=1.3 \mathrm{~Hz}, 3 \mathrm{H}), 2.00(\mathrm{~s}, 3 \mathrm{H}), 1.87(\mathrm{~d}, J=1.0 \mathrm{~Hz}, 3 \mathrm{H}), 1.33-$ $1.51(\mathrm{~m}, 2 \mathrm{H}), 0.99(\mathrm{~d}, J=6.8 \mathrm{~Hz}, 3 \mathrm{H}), 0.90(\mathrm{~s}, 9 \mathrm{H}), 0.85(\mathrm{t}, J=7.4 \mathrm{~Hz}, 3$ $\mathrm{H}), 0.05$ (s, $6 \mathrm{H})$.

${ }^{13} \mathrm{C}$ NMR (101 MHz, $\left.\mathrm{CDCl}_{3}\right): \delta=156.82,144.25,135.41,133.96$, 133.73, 128.79, 124.49, 117.63, 94.91, 77.32, 38.02, 27.50, 26.06, $19.59,18.28,17.09,14.78,14.40,10.13,-4.07,-4.32$.

HRMS (ESI): $m / z$ [M + Na] $]^{+}$calcd for $\mathrm{C}_{23} \mathrm{H}_{39} \mathrm{NONaSi}$ : 396.2699; found: 396.2695 .

\section{Funding Information}

This work was supported by the Academy of Finland (project number 266369) and (to O.V.K.) the FP7 InnovaBalt project (contract $\mathrm{Nr} .316149$ ). The authors would like to acknowledge the networking contribution by COST Action CM1407 "Challenging organic syntheses 
inspired by nature - from natural products chemistry to drug discovery".

\section{Acknowledgment}

The authors would like to acknowledge Tiia Seppä for HRMS measurements.

\section{Supporting Information}

Supporting information for this article is available online at https://doi.org/10.1055/s-0037-1610387.

\section{References}

(1) (a) Kato, Y.; Fusetani, N.; Matsunaga, S.; Hashimoto, K. J. Am. Chem. Soc. 1986, 108, 2780. (b) Kato, Y.; Fusetani, N.; Matsunaga, S.; Hashimoto, K.; Koseki, K. J. Org. Chem. 1988, 53, 3930. (c) Calyculins E-H: Matsunaga, S.; Fujiki, H.; Sakata, D.; Fusetani, N. Tetrahedron 1991, 47, 2999.

(2) Dumdei, E. J.; Blunt, J. W.; Munro, M. H. G.; Pannell, L. K. J. Org. Chem. 1997, 62, 2636.

(3) Matsunaga, S.; Wakimoto, T.; Fusetani, N. J. Org. Chem. 1997, 62, 2640.

(4) Matsunaga, S.; Wakimoto, T.; Fusetani, N.; Suganuma, M. Tetrahedron Lett. 1997, 38, 3763.

(5) Steube, K. G.; Meyer, C.; Proksch, P.; Supriyono, A.; Sumaryono, W.; Drexler, H. G. Anticancer Res. 1998, 18, 129.

(6) Fu, X.; Schmitz, F. J.; Kelly-Borges, M.; McCready, T. L.; Holmes, C. F. B. J. Org. Chem. 1998, 63, 7957.

(7) Wakimoto, T.; Egami, Y.; Abe, I. Nat. Prod. Rep. 2016, 33, 751.

(8) Fagerholm, A. E.; Habrant, D.; Koskinen, A. M.P. Mar. Drugs 2010, 8, 122.

(9) Evans, D. A.; Gage, J. R.; Leighton, J. L.J. Am. Chem. Soc. 1992, 114, 9434.

(10) Tanimoto, N.; Gerritz, S. W.; Sawabe, A.; Noda, T.; Filla, S. A.; Masamune, S. Angew. Chem., Int. Ed. Engl. 1994, 33, 673.

(11) Yokokawa, F.; Hamada, Y.; Shioiri, T. Chem. Commun. 1996, 871.

(12) Smith, A. B. III.; Friestad, G. K.; Duan, J. J.-W.; Barbosa, J.; Hull, K. G.; Iwashima, M.; Qiu, Y.; Spoors, P. G.; Bertounesque, E.; Salvatore, B. A. J. Org. Chem. 1998, 63, 7596.

(13) Ogawa, A. K.; Armstrong, R. W. J. Am. Chem. Soc. 1998, 121, 12435.

(14) Anderson, O. P.; Barrett, A. G. M.; Edmunds, J. J.; Hachiya, S.-I.; Hendrix, J. A.; Horita, K.; Malecha, J. W.; Parkinson, C. J.; VanSickle, A. Can. J. Chem. 2001, 79, 1562.

(15) Fragment A: (a) Koskinen, A. M.P.; Chen, J. Tetrahedron Lett. 1991, 32, 6977. (b) Passiniemi, M.; Koskinen, A. M. P. Synthesis 2010, 2816. Fragment B: (c) Koskinen, A. M.P.; Pihko, P. M. Tetrahedron Lett. 1994, 35, 7417. (d) Pihko, P. M.; Koskinen, A. M. P. J. Org. Chem. 1998, 63, 92. Fragment C: (e) Habrant, D.; Koskinen, A. M. P. Org. Biomol. Chem. 2010, 8, 4364.

(16) Pihko, P. M.; Koskinen, A. M. P. Synlett 1999, 1966.

(17) Barrett, A. G. M.; Edmunds, J. J.; Hendrix, J. A.; Horita, K.; Parkinson, C. J.J. Chem. Soc., Chem. Commun. 1992, 1238.

(18) (a) Yokokawa, F.; Hamada, Y.; Shioiri, T. Tetrahedron Lett. 1993, 34, 6559. (b) Matsubara, J.; Nakao, K.; Shioiri, T. Tetrahedron Lett. 1992, 33, 4187.
(19) Scarlato, G. R.; DeMattei, J. A.; Chong, L. S.; Ogawa, A. K.; Lin, M. R.; Armstrong, R. W.J. Org. Chem. 1996, 61, 6139.

(20) Negishi, E. Bull. Chem. Soc. Jpn. 2007, 80, 233.

(21) Ronson, T. O.; Taylor, R. J. K.; Fairlamb, I. J. S. Tetrahedron 2015, $71,989$.

(22) Heravi, M. M.; Hashemi, E.; Azimian, F. Tetrahedron 2014, 70, 7.

(23) Heravi, M. M.; Hashemi, E. Tetrahedron 2012, 68, 9145.

(24) Kosugi, M.; Fugami, K. J. Organomet. Chem. 2002, 653, 50.

(25) Negishi, E. Angew. Chem. Int. Ed. 2011, 50, 6738.

(26) Beletskaya, I. P.; Cheprakov, A. V. Chem. Rev. 2000, 100, 3009.

(27) Miyaura, N.; Yamada, K.; Suzuki, A. Tetrahedron Lett. 1979, 20 , 3437.

(28) Corey, E. J.; Katzenellenbogen, J. A.; Posner, G. H. J. Am. Chem. Soc. 1967, 89, 4245.

(29) Betzer, J.-F.; Delaloge, F.; Muller, B.; Pancrazi, A.; Prunet, J.J. Org. Chem. 1997, 62, 7768.

(30) Jung, M. E.; Light, L. A. Tetrahedron Lett. 1982, 23, 3851.

(31) Zhang, H. X.; Guibe, F.; Balavoine, G. J. Org. Chem. 1990, 55, 1857.

(32) Huang, Z.; Negishi, E. Org. Lett. 2006, 8, 3675.

(33) (a) Cornil, J.; Echeverria, P.-G.; Phansavath, P.; RatovelomananaVidal, V.; Guérinot, A.; Cossy, J. Org. Lett. 2015, 17, 948. (b) Madden, K. S.; David, S.; Knowles, J. P.; Whiting, A. Chem. Commun. 2015, 51, 11409. (c) Jeffery, T. Tetrahedron Lett. 1985, 26, 2667.

(34) Desai, N. B.; McKelvie, N.; Ramirez, F. J. Am. Chem. Soc. 1962, 84, 1745.

(35) Roush, W. R.; Moriarty, K. J.; Brown, B. B. Tetrahedron Lett. 1990, 31,6509 .

(36) Kim, K.; Lauher, J. W.; Parker, K. A. Org. Lett. 2012, 14, 138.

(37) Sofiyev, V.; Navarro, G.; Trauner, D. Org. Lett. 2008, 10, 149.

(38) Jacobsen, M. F.; Moses, J. E.; Adlington, R. M.; Baldwin, J. E. Tetrahedron 2006, 62, 1675 .

(39) Zeng, X.; Qian, M.; Hu, Q.; Negishi, E. Angew. Chem. Int. Ed. 2004, 43, 2259.

(40) Källström, S.; Erkkilä, A.; Pihko, P. M.; Sjöholm, R.; Sillanpää, R.; Leino, R. Synlett 2005, 751.

(41) Corey, E. J.; Fuchs, P. L. Tetrahedron Lett. 1972, 13, 3769.

(42) Hart, D. W.; Blackburn, T. F.; Schwartz, J. J. Am. Chem. Soc. 1975 97, 679.

(43) Dale, J. A.; Dull, D. L.; Mosher, H. S. J. Org. Chem. 1969, 34, 2543.

(44) Ward, D. E.; Rhee, C. K. Tetrahedron Lett. 1991, 32, 7165.

(45) (a) Crossman, J. S.; Perkins, M. V. J. Org. Chem. 2006, 71, 117. (b) Brown, H. C.; Bhat, K. S. J. Am. Chem. Soc. 1986, 108, 5919. (c) Kalaitzakis, D.; Smonou, I. Eur. J. Org. Chem. 2012, 43.

(46) Moure, A. L.; Gómez Arrayás, R.; Cárdenas, D. J.; Alonso, I.; Carretero, J. C. J. Am. Chem. Soc. 2012, 134, 7219.

(47) Mitsudo, T.; Fischetti, W.; Heck, R. F. J. Org. Chem. 1984, 49, 1640.

(48) Okada, A.; Watanabe, K.; Umeda, K.; Miyakado, M. Agric. Biol. Chem. 1991, 55, 2765.

(49) Zurwerra, D.; Gertsch, J.; Altmann, K.-H. Org. Lett. 2010, 12, 2302.

(50) Yang, Q.; Draghici, C.; Njardarson, J. T.; Li, F.; Smith, B. R.; Das, P. Org. Biomol. Chem. 2014, 12, 330.

(51) Placzek, A. T.; Gibbs, R. A. Org. Lett. 2011, 13, 3576.

(52) Paterson, I.; Anderson, E. A.; Dalby, S. M.; Lim, J. H.; Maltas, P.; Loiseleur, O.; Genovino, J.; Moessner, C. Org. Biomol. Chem. 2012, 10, 5861. 